\title{
AGU Advances
}

\section{RESEARCH ARTICLE 10.1029/2021AV000469}

Peer Review The peer review history for this article is available as a PDF in the Supporting Information.

Key Points:

- 113-236 $\mathrm{TgC}$ of $\mathrm{CO}_{2}$ were released through biomass burning, and 19-52 $\mathrm{TgC}$ of $\mathrm{CO}_{2}$ through reduced ecosystem productivity

- Transition to cool-wet conditions resulted in robust recovery for unburned ecosystems but not for burned forests

- Space-based remote sensing of trace gases and MODerate-resolution Imaging Spectroradiometer reflectances provide strong constraints on carbon cycle anomalies from extreme events

Supporting Information: Supporting Information may be found in the online version of this article.

Correspondence to:

B. Byrne,

brendan.k.byrne@jpl.nasa.gov

\section{Citation:}

Byrne, B., Liu, J., Lee, M., Yin, Y., Bowman, K. W., Miyazaki, K., et al. (2021). The carbon cycle of southeast Australia during 2019-2020: Drought, fires, and subsequent recovery. $A G U$ Advances, 2, e2021AV000469. https://doi. org/10.1029/2021 AV000469

Received 1 MAY 2021 Accepted 18 OCT 2021

\section{The Carbon Cycle of Southeast Australia During 2019-2020: Drought, Fires, and Subsequent Recovery}

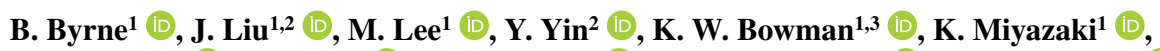

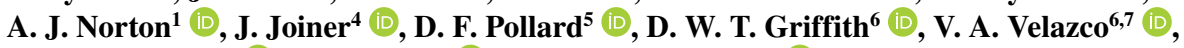 \\ N. M. Deutscher' ${ }^{(D)}$, N. B. Jones ${ }^{6}$ iD, and C. Paton-Walsh 6 (iD
}

${ }^{1}$ Jet Propulsion Laboratory, California Institute of Technology, Pasadena, CA, USA, ${ }^{2}$ Division of Geological and Planetary Sciences, California Institute of Technology, Pasadena, CA, USA, ${ }^{3}$ Joint Institute for Regional Earth System Science and Engineering, University of California, Los Angeles, Los Angeles, CA, USA, ${ }^{4}$ Laboratory of Atmospheric Chemistry and Dynamics, NASA Goddard Space Flight Center, Greenbelt, MD, USA, ${ }^{5}$ National Institute of Water and Atmospheric Research Ltd. (NIWA), Lauder, New Zealand, ${ }^{6}$ Centre for Atmospheric Chemistry, School of Earth, Atmospheric and Life Sciences, University of Wollongong, Wollongong, NSW, Australia, ${ }^{7}$ Deutscher Wetterdienst, German Meteorological Service Meteorological Observatory, Hohenpeissenberg, Germany

Abstract 2019 was the hottest and driest year on record for southeast Australia leading to bushfires of unprecedented extent. Ecosystem carbon losses due to drought and fire are believed to have been substantial, but have not been well quantified. Here, we utilize space-based measurements of trace gases (TROPOspheric Monitoring Instrument $\mathrm{X}_{\mathrm{CO}}$, Orbiting Carbon Observatory $2 \mathrm{X}_{\mathrm{CO}_{2}}$ ) and up-scaled GPP (FluxSat GPP) to quantify the carbon cycle anomalies resulting from drought and fire in southeast Australia during the 2019-2020 growing season. We find that biomass burning released 113-236 $\mathrm{TgC}$ of $\mathrm{CO}_{2}$ while drought and fire-induced anomalies in net ecosystem exchange reduced growing season carbon uptake by an additional 19-52 $\mathrm{TgC}$ of $\mathrm{CO}_{2}$. These carbon losses were concentrated during the spring and early summer, when hot-dry conditions were most severe. A shift to cooler conditions with above average rainfall during February is found to result in a partial recovery and greening in unburned ecosystems, but not in fire-impacted areas. The net 2019-2020 carbon loss substantially exceeded interannual variations in net uptake over 2010-2019 estimated from top-down constraints ( $\sim 5 \sigma$ anomaly), and exceeded Australia's annual fossil fuel emissions ( $\sim 104 \mathrm{TgC}$ year $\left.^{-1}\right)$. Top-down constraints show that the regional carbon budget is strongly regulated by climate variability, and suggest that cool-wet conditions are required for a rapid recovery of carbon stocks. This has implications for the regional carbon budget as more frequent climate-change-driven heat and drought events may increase the frequency of fire events and the recovery time of ecosystems, threatening the carbon stocks of the region.

Plain Language Summary Extreme climate events can have a large impacts on the carbon cycle of ecosystems. Droughts suppress photosynthesis, reducing the amount of $\mathrm{CO}_{2}$ absorbed from the atmosphere, and fires release $\mathrm{CO}_{2}$ to the atmosphere through combustion. In this study, we use satellite observations to quantify the disruption to the carbon cycle due to drought and bushfires in southeast Australia during 2019-2020. The drought and bushfires resulted in a carbon loss from these ecosystems that is greater than Australia's annual fossil fuel emissions, although the carbon is expected to be drawn back into these ecosystems as the forests recover. This study highlights our ability to track the carbon cycle from space.

\section{Introduction}

Extreme drought and heat events can result in single-year carbon losses equal to many years of carbon sequestration (Bastos et al., 2014; Ciais et al., 2005). Hot-dry conditions can directly suppress both gross primary productivity (GPP) and ecosystem respiration (TER), with greater suppression of GPP leading to carbon loss (Reichstein et al., 2007; Sippel et al., 2018). These conditions also dry fuels, increase litterfall, and elevate levels of tree mortality, all of which may trigger additional carbon losses by means of wildfire (Abram et al., 2020; D. M. J. S. Bowman et al., 2009). Impacted ecosystems often experience legacy effects that can impact the carbon cycling for years after the extreme events have passed (Batllori et al., 2020; Frank et al., 2015; Lindenmayer et al., 2021).

Southeast Australia (Figure 1) has a highly variable climate (Harris \& Lucas, 2019; King et al., 2020), and frequently experiences both drought and fire. In fact, this susceptibility to fire has been a key factor in the evolution of the regional flora and fauna, acting as a process of disturbance and also regeneration (Bowman, 2000;
(C) 2021 Jet Propulsion Laboratory, California Institute of Technology. This is an open access article under the terms of the Creative Commons Attribution License, which permits use, distribution and reproduction in any medium, provided the original work is properly cited. 

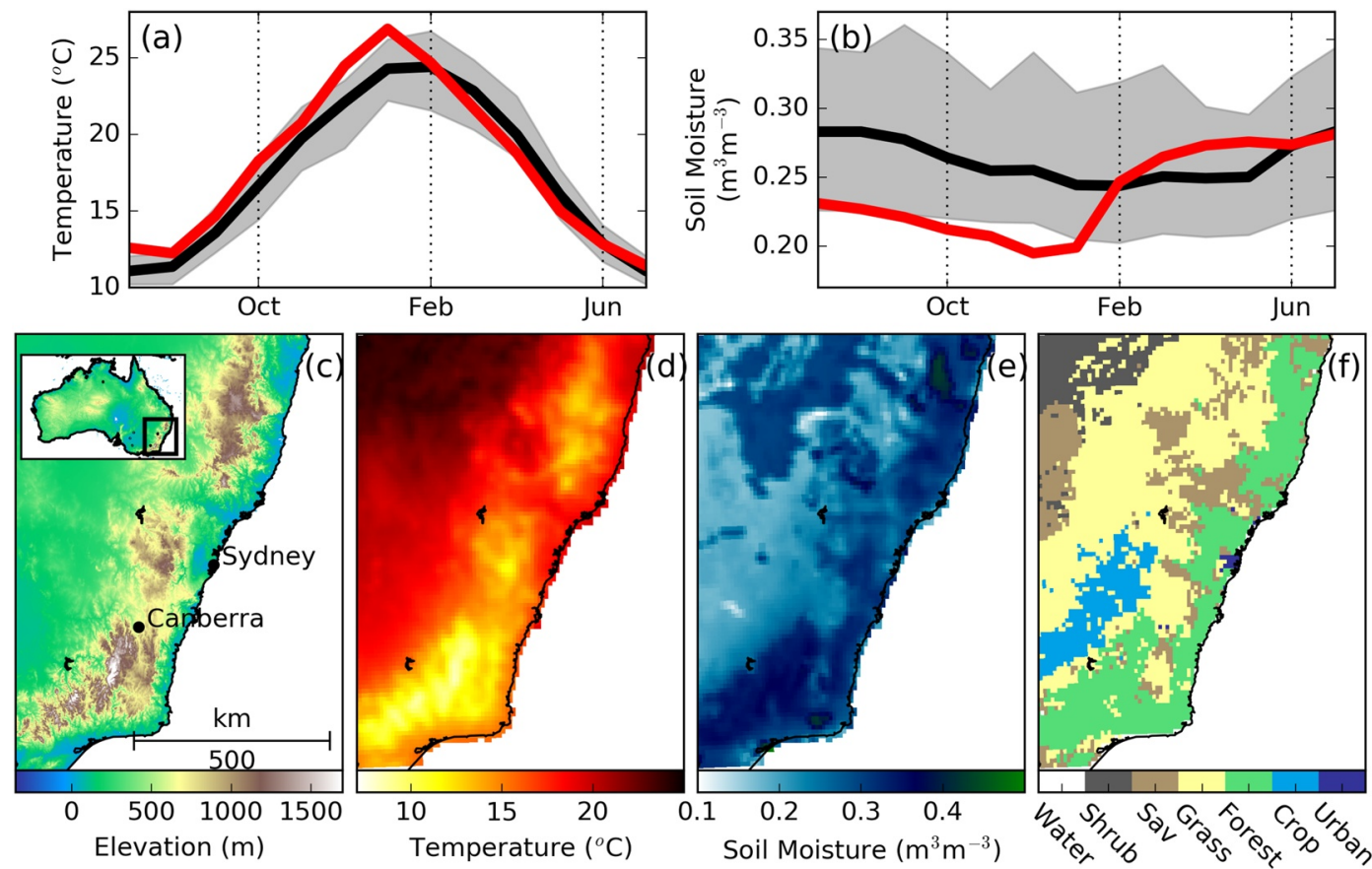

Figure 1. Climate and Geography of southeast Australia. (a) ERA5 Land soil temperature and (b) soil moisture over southeast Australia for 2010-2018 in black (shaded area showing the range) and 2019-2020 in red. (c) Surface elevation, (d) 2010-2018 mean soil temperature, (e) 2010-2018 mean soil moisture, and (f) MODIS IGBP vegetation type.

Burrows, 2002). However, the region is experiencing more frequent, extensive and severe fires (Pitman et al., 2007; Stephens et al., 2013), a trend that is expected to continue with climate change (Abatzoglou et al., 2019; Di Virgilio et al., 2019; Dowdy et al., 2019; Perkins-Kirkpatrick \& Gibson, 2017). Despite the adaptations of Australian ecosystems to fire, these changing fire regimes have been shown to impact tree mortality (Bennett et al., 2016; D. M. J. S. Bowman et al., 2014) and threaten the persistence of some forest biomes in Australia (D. M. J. S. Bowman, Williamson, Price, et al., 2020; Fairman et al., 2016; D. M. J. S. Bowman et al., 2014), including their carbon stores. Thus, monitoring the response of ecosystems in southeast Australia to extreme drought, heat and fire is critical for understanding how the carbon balance of this region will evolve under climate change.

Since 2017, southeast Australia has been in drought, with the 2017-2019 period having the largest 3 year rainfall deficit since 1900 (King et al., 2020). These conditions have been most extreme during 2019, which was the hottest and driest year recorded in southeast Australia (Abram et al., 2020; Bureau of Meteorology, 2020), provoking one of the worst bushfires seasons in recorded history (Boer et al., 2020; Collins, Bradstock, et al., 2021; D. M. J. S. Bowman et al., 2021; Deb et al., 2020; King et al., 2020; Nolan et al., 2020; Ward et al., 2020). These extreme conditions subsided in early February 2020 with heavy rainfall and cooler conditions that persisted throughout the austral autumn. This combination of drought and fire followed by heavy rainfall imparts a large and complex perturbation on the carbon cycle of the region and impacted forested regions that cover much of the southeast coast and mountainous regions, and more arid savanna, grassland and cropland ecosystems further inland (Figure 1).

The impact of extreme drought and heat events on ecosystems are complex and challenging to monitor. Ecosystem responses are sensitive to the specific characteristics of the event, such as the intensity and timing (Bastos et al., 2014; De Boeck et al., 2011; Denton et al., 2017; Frank et al., 2015), legacy effects from previous disturbances (Bowd et al., 2021; Longo et al., 2020) and vegetation type (Turner et al., 2020; Zhang et al., 2016). The recent expansions of space-based observing systems of carbon-cycle-relevant quantities are now providing the opportunity for finer scale quantification of carbon cycle perturbations and more detailed understanding of the response of ecosystems to extreme drought, heat, and fire (Byrne, Liu, Lee, et al., 2020; Byrne, Liu, Bloom, et al., 2020; Byrne et al., 2019; Turner et al., 2020; Yin, Bloom, et al., 2020). In this study, we utilize space-based 
observations to provide a comprehensive analysis of the carbon cycle perturbations due to extreme drought, heat and fire during the 2019-2020 growing season in southeast Australia.

We combine observations from multiple satellites to quantify the carbon cycle anomalies within southeast Australia. We employ TROPOspheric Monitoring Instrument (TROPOMI) CO column abundance measurements (Borsdorff et al., 2018; Landgraf et al., 2016) to quantify biomass burning emissions. Anomalies in net ecosystem exchange (NEE, which is defined as the residual between TER and GPP) are obtained by combining top-down constraints on net surface-atmosphere $\mathrm{CO}_{2}$ fluxes from column-averaged dry-air mole fractions of $\mathrm{CO}_{2}\left(\mathrm{X}_{\mathrm{CO}_{2}}\right)$ measurements from the Orbiting Carbon Observatory 2 (OCO-2) (Crisp et al., 2017; Eldering et al., 2017) with estimates of GPP anomalies from FluxSat (Joiner \& Yoshida, 2020), which produces GPP from MODerate-resolution Imaging Spectroradiometer (MODIS) reflectances trained against FLUXNET sites.

The combination of these newly available observations offers a unique opportunity to monitor individual components of the carbon cycle anomalies across southeast Australia during 2019-2020. Specifically, we aim to answer: How much $\mathrm{CO}_{2}$ was released to the atmosphere due to drought and biomass burning, respectively? How did this event impact forest and non-forest ecosystems differently? What were the differences in carbon cycle perturbations between burned and unburned ecosystems? And how does 2019-2020 compare with previous years? To that end, we first quantify biomass burning emissions of CO using the TROPOMI observations, which are converted to $\mathrm{CO}_{2}$ emissions (Section 3.1). Next, an anomaly in atmospheric $\mathrm{CO}_{2}\left(\Delta \mathrm{CO}_{2}\right)$ is derived using the OCO-2 measurements (Section 3.2). This top-down constraint is then combined with estimates of GPP anomalies using FluxSat to derive NEE anomalies over the 2019-2020 growing season (Section 3.3). We then synthesize these estimates and present the evolution of carbon cycle anomalies over the 2019-2020 growing season (Section 4), and compare this event with the regional carbon budget over the 2010-2019 period (Section 5). This is followed by a discussion of our biomass burning emission estimates in the context of previous bottom-up and top-down estimates (Section 6.1), the implications of this extreme event for the carbon cycle of southeast Australia (Section 6.2), and the uncertainties and remaining challenges in estimating carbon fluxes from extreme events (Section 6.3). Finally, we provide our conclusions in Section 7.

\section{Environmental and Geographical Data}

Environmental and geographical data are used to help interpret the carbon cycle anomalies. We examine the covariations of carbon cycle anomalies with variations in soil temperature and soil moisture from ERA5-Land reanalysis (Munoz Sabater, 2019), generated using Copernicus Climate Change Service Information 2020. For this analysis, we calculate the area-weighted soil moisture and temperature over the top $1 \mathrm{~m}$ of soil. Vegetation land cover is obtained from the MODIS land cover dataset (MCD12C1; Friedl \& Sulla-Menashe, 2015) and elevation data are obtained from ETOPO1 (Amante \& Eakins, 2009).

\section{3. $\mathrm{CO}_{2}$ Flux Estimates}

Figure 2 shows a schematic diagram of the methods used to estimate biomass burning emissions and anomalies in $\operatorname{NEE}\left(\Delta \mathrm{NEE}\right.$ ). Biomass burning $\mathrm{CO}_{2}$ emissions are estimated from TROPOMI $\mathrm{X}_{\mathrm{CO}}$ measurements (Section 3.1). First, emissions of $\mathrm{CO}$ are estimated through flux inversion analyses that assimilate TROPOMI $\mathrm{X}_{\mathrm{CO}}$ measurements. Then $\mathrm{CO}$ emissions are converted to $\mathrm{CO}_{2}$ emissions using emission factors.

Estimates of $\triangle \mathrm{NEE}$ are obtained through combining several different data sources. First, we infer a top-down $\mathrm{CO}_{2}$ anomaly signal $\left(\Delta \mathrm{X}_{\mathrm{CO}_{2}}\right)$ due to anomalies in biosphere-atmosphere $\mathrm{CO}_{2}$ fluxes (Section 3.2). Then we subtract the $\Delta \mathrm{X}_{\mathrm{CO}_{2}}$ signal due to biomass burning emissions, giving $\Delta \mathrm{X}_{\mathrm{CO}_{2}}$ due to $\Delta \mathrm{NEE}$. This provides a constraint on the magnitude of $\triangle$ NEE. Finally, we estimate the spatiotemporal structure of $\Delta$ NEE by combining the atmospheric $\mathrm{CO}_{2}$ constraints with FluxSat GPP (Section 3.3). Note that the $\mathrm{CO}_{2}$ flux and atmospheric $\mathrm{X}_{\mathrm{CO}_{2}}$ are related to fluxes using a chemical transport model (Section 3.1.1).

Atmospheric chemical transport simulations and flux inversions are performed with the Greenhouse Gas Framework-Flux (GHGF-Flux) inversion system. GHGF-Flux is a flux inversion system developed under the NASA Carbon Monitoring System Flux (CMS-Flux) project (https://cmsflux.jpl.nasa.gov), and inherits the chemistry transport model from GEOS-Chem and its adjoint (Henze et al., 2007; Liu et al., 2014). Chemical transport is driven by the Modern Era Retrospective Analysis for Research and Applications, Version 2 meteorology 


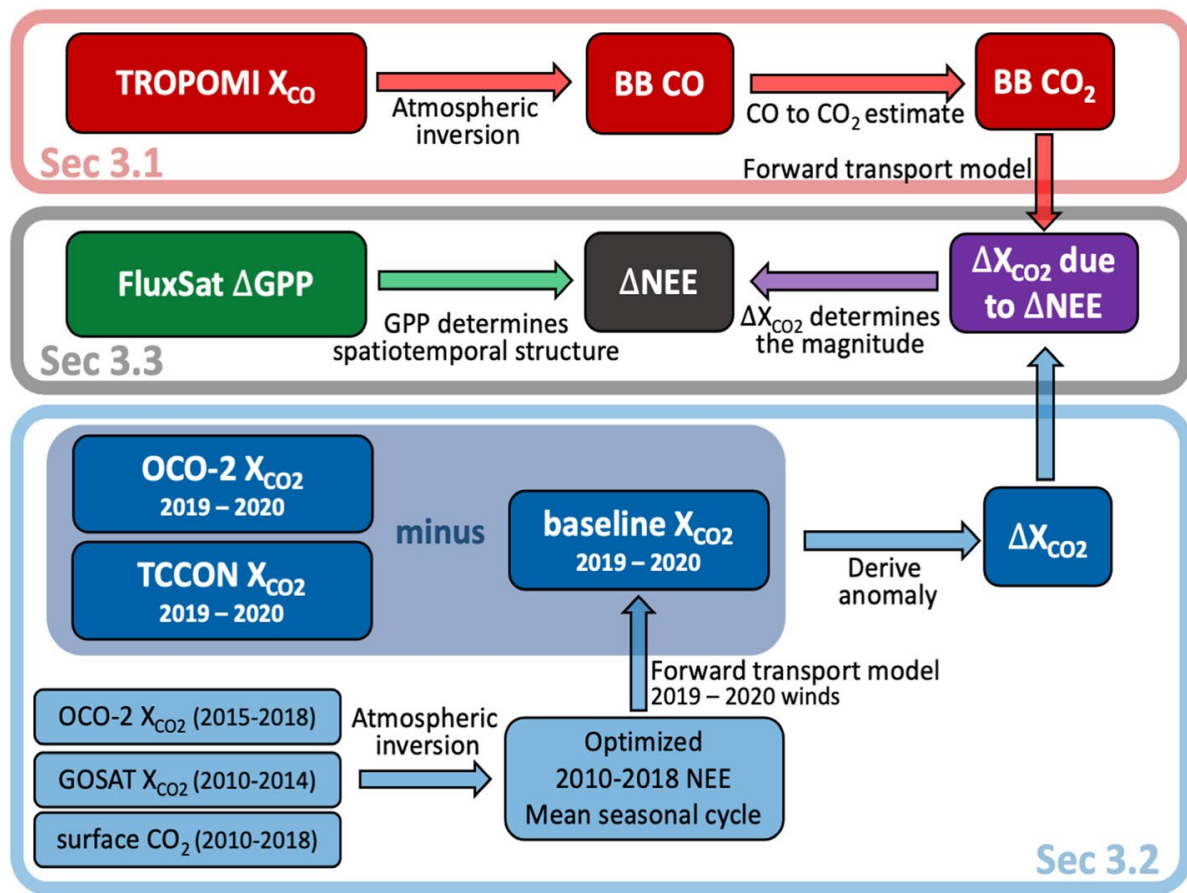

Figure 2. Schematic diagram of the method used to derive biomass burning and $\triangle \mathrm{NEE} \mathrm{CO}_{2}$ fluxes. Biomass burning emissions are based on TROPOspheric Monitoring Instrument $\mathrm{X}_{\mathrm{CO}}$ measurements (shown in red). $\mathrm{CO}_{2}$-based estimates of $\Delta \mathrm{X}_{\mathrm{CO}_{2}}$ are estimated from measurements of atmospheric $\mathrm{CO}_{2}$ (shown in blue). First, NEE fluxes over 2010-2018 are estimated through flux inversion analysis (shown in light blue). Combining the mean NEE seasonal cycle over this period with a chemical transport model, we simulate the expected 2019-2020 baseline atmospheric $\mathrm{CO}_{2}$ fields given climatological fluxes. Then, the difference between the actual 2019-2020 measurements and the expected $\mathrm{X}_{\mathrm{CO}_{2}}$ gives the anomaly in atmospheric $\mathrm{X}_{\mathrm{CO}_{2}}$ (shown in blue shaded area). $\triangle \mathrm{NEE}$ is then estimated from combining all of the constraints. The spatiotemporal structure of $\triangle \mathrm{NEE}$ is based on FluxSat gross primary productivity (shown in green), while the magnitude is derived from combining the top-down and biomass-burning-derived $\Delta \mathrm{CO}_{2}$ estimates (shown in purple).

produced with version 5.12.4 of the Goddard Earth Observing System (GEOS) atmospheric data assimilation system (Gelaro et al., 2017). To perform tracer transport, these fields are regridded to the desired horizontal resolution and archived with a temporal resolution of three hours except for surface quantities and mixing depths, which have a temporal resolution of one hour. Flux inversions are performed using 4-D variational assimilation (4D-Var), with the details provided in the subsections.

\subsection{Biomass Burning Emissions}

Atmospheric CO inversions have been shown to be an effective top-down approach for estimating fire carbon emissions (Langenfelds et al., 2002; Liu et al., 2017; Yin, Bloom, et al., 2020; Yin et al., 2015, 2016; Zheng et al., 2019). Here, we perform atmospheric CO inversions to estimate biomass burning emissions by assimilating TROPOMI retrievals of $\left(\mathrm{X}_{\mathrm{CO}}\right)$. TROPOMI is a grating spectrometer aboard ESA's Sentinel-5 Precursor (S-5P) satellite that measures Earth reflected radiances (Veefkind et al., 2012). CO total column densities are retrieved in the shortwave infrared (around $2.3 \mu \mathrm{m}$ ) using the Shortwave Infrared CO Retrieval algorithm (Landgraf et al., 2016). Retrieved CO total column densities are then converted to dry-air mole fractions of CO $\left(\mathrm{X}_{\mathrm{CO}}\right)$ using the dry-air surface pressure and hypsometric equation. The column averaging kernel is similarly converted to mole-fraction space.

Biomass burning $\mathrm{CO}$ emissions are estimated using one-way nested flux inversions over Australia $\left(100^{\circ}-177.5^{\circ}\right.$ $\mathrm{E}$ and $0^{\circ}-60^{\circ} \mathrm{S}$ ) at $0.5^{\circ} \times 0.625^{\circ}$ spatial resolution. Nested flux inversions are performed from 5 November 2019 through 14 January 2020 (to cover the period with the majority of fires) and assimilate TROPOMI $\mathrm{X}_{\mathrm{CO}}$ super-obs (aggregated observations) to optimize scaling factors for each gridcell over the entire period. Details 
on the inversion configuration are provided in Appendix A. The posterior scaling factors are then applied over the entire October-May time period (note that biomass burning emissions are small outside of the inversion period).

Eight nested flux inversions are performed, which vary in prior biomass burning emissions, quantities optimized, and boundary conditions (Table 1). Differences in flux inversion configuration are employed to test the sensitivity of posterior fluxes to the inversion set-up. We employ two different biomass burning emissions data sets as prior CO fluxes, namely the Global Fire Emissions Database version 4 (GFED4.1s; van der Werf et al., 2017) and Global Fire Assimilation System (GFAS; Kaiser et al., 2012). GFED4.1s provides estimates of biomass burning using MODIS $500 \mathrm{~m}$ burned area (Giglio et al., 2013), $1 \mathrm{~km}$ thermal anomalies, and $500 \mathrm{~m}$ surface reflectance observations to statistically estimate burned area associated with small fires (Randerson et al., 2012). GFAS v1.2 provides estimates of daily biomass burning emissions by assimilating MODIS fire radiative power observations (Di Giuseppe et al., 2018; Kaiser et al., 2012). For both data sets, we incorporate the impact of the diurnal cycle based on $\mathrm{Mu}$ et al. (2011). The inversions also differ by either prescribing or optimizing diurnal variations on biomass burning emissions. Finally, inversions are either run using boundary conditions from a global TROPOMI flux inversion or with these boundary conditions adjusted by adding $10 \mathrm{ppb}$ (roughly equivalent to the mean data-model difference) at all levels and times to test the sensitivity of the nested CO inversion to lateral boundary conditions.

Video 1 shows the spatial distribution of the mean posterior fluxes and $\mathrm{X}_{\mathrm{CO}}$ measurements across southeast Australia. Biomass burning emissions were most concentrated in forest ecosystems along the coast and further inland along the border between New South Wales and Victoria. Posterior CO emissions are increased for all inversion configurations, with a posterior mean $\mathrm{CO}$ emission estimate of 15.6 $\mathrm{TgC}$ (range: 9.7-24.3 $\mathrm{TgC}$ ), relative to prior emission estimates of 11.4 TgC for GFED and 5.8 TgC for GFAS over the growing season. The largest source of spread among posterior fluxes is due to the prior biomass burning flux employed, with GFED-based inversions giving larger posterior emissions than GFAS-based inversions (see Figure S2 in Supporting Information S1).

The performance of the nested $\mathrm{CO}$ flux inversions are evaluated by comparing the posterior $\mathrm{CO}$ fields with the TROPOMI $\mathrm{X}_{\mathrm{CO}}$ measurements, independent $\mathrm{X}_{\mathrm{CO}}$ measurements from the nearby Wollongong (Griffith et al., 2014) and Lauder (Pollard et al., 2017, 2019) Total Column Carbon Observing Network (TCCON; Wunch et al., 2011) sites, the Cross-track Infrared Sounder (CrIS) and surface-based flask and in situ measurements at the nearby Cape Grim (CGO), Baring Head (BHD), and Lauder (LAU) sites. CrIS is a Fourier Transform Spectrometer aboard the satellite Suomi-NPP and has a spectral resolution of $0.625 \mathrm{~cm}^{-1}$ and a ground pixel diameter of $14 \mathrm{~km}$ at nadir. CrIS and TROPOMI make collocated measurements because Suomi-NPP and Sentinel 5p are in a tandem orbit with a roughly 10 min separation. However, CrIS takes measurements in both day and night. The retrieval of CO uses the MUlti-SpEctra, MUlti-SpEcies, Multi-SEnsors (MUSES) algorithm (Fu et al., 2016) that is based on the optimal estimation method with heritage from the tropospheric emission spectrometer (K. W. Bowman et al., 2006). We generate $\mathrm{X}_{\mathrm{CO}}$ measurements from version 1.8 of the $\mathrm{L} 2$ tropospheric $\mathrm{CO}$ profile product, and compare posterior $\mathrm{CO}$ fields against daytime and nighttime $\mathrm{X}_{\mathrm{CO}}$ measurements separately.

As trace gas emissions from fires are impacted by pyroconvective motions (that are not well represented in chemical transport models), we evaluate the posterior fluxes with two sets of model runs that release the CO emissions at different model levels. In one set of runs, we release the emissions at the surface (as was done in the inversion), while in the second set we release $\mathrm{CO}$ emissions at the injection height (mean altitude of maximum injection) simulated by a plume rise model (IS4FIRES; Rémy et al., 2017), which was provided with the GFAS emission data. Here we provide a brief summary of the evaluation, while a detailed evaluation of the flux inversions is presented in Text S1 in Supporting Information S1. Posterior fluxes generally show better agreement with the TROPOMI, TCCON, CrIS, and the in situ/flask measurements. This is true for all measurements and a subset of measurements that are biomass burning sensitive. However, posterior $\mathrm{CO}$ fluxes tend to underestimate $\mathrm{X}_{\mathrm{CO}}$ for biomass-burning-sensitive measurements (but less so than the prior). This residual mismatch is likely related to transport model errors, as the modeled observations often show differences in plume structure (Video 1). Furthermore, the transport model underestimates vertical motions around the bushfires, which were impacted by pyroconvection. The impact of weak modeled vertical motions can be seen in Video 1c,d. The column averaging kernel for TROPOMI shows greater sensitivity to CO between $400 \mathrm{hPa}$ and the surface, while CrIS shows greater sensitivity to $\mathrm{CO}$ in the upper troposphere. Both TROPOMI and CrIS show mean $\mathrm{X}_{\mathrm{CO}}$ mole fractions greater than $200 \mathrm{ppb}$ in southeast Australia for the duration of the biomass burning over November-January. However, 
posterior data-model mismatches are much less positive for TROPOMI than for CrIS, implying that vertical motions are underestimated and the $\mathrm{CO}$ emissions do not reach the upper troposphere to the levels observed.

Finally, to estimate $\mathrm{CO}_{2}$ biomass burning emissions we apply the ratio of $\mathrm{CO}_{2}$ to $\mathrm{CO}$ emission factors (that are constant in time). We apply the emission factors from the biomass burning database used as the prior (e.g., either GFAS or GFED). The emission ratios are variable by vegetation type, but aggregating for fires across Australia gives effective $\mathrm{CO}_{2} / \mathrm{CO}$ emission ratios of $12.01 \mathrm{gC} \mathrm{gC}^{-1}$ for GFED and $11.30 \mathrm{gC} \mathrm{gC}^{-1}$ for GFAS. Differences are primarily driven by differences in emission factors for forest emissions, but are within the natural variation of emission factors reported by Akagi et al. (2011) (see Text S2 and Figure S4 in Supporting Information S1) and reported for Australian forests (Table S5 in Supporting Information S1) (Guérette et al., 2018; Paton-Walsh et al., 2014). The impact of emission factor uncertainty is further discussed in Section 6.3.2.

\subsubsection{Atmospheric $\Delta \mathrm{CO}_{2}$ Signal Simulation}

We simulate the biomass burning $\mathrm{X}_{\mathrm{CO}_{2}}$ anomaly signal $\left(\Delta \mathrm{X}_{\mathrm{CO}_{2}}\right.$ BB $)$ by running the nested chemical transport model. The $\Delta \mathrm{X}_{\mathrm{CO}_{2}}$ вB signal is calculated by performing simulations with climatological fluxes and with the climatological fluxes plus the biomass burning estimates, then taking the difference between these two simulations at the OCO-2 and TCCON measurements locations to isolate the signal due to biomass burning. We simulate OCO-2 good-quality land (land glint and land nadir) and ocean glint super-obs (aggregated to $0.5^{\circ} \times 0.5^{\circ}$ resolution grids following Liu et al. (2017), with the additional requirement that there must be a minimum of three OCO-2 observations within each $0.5^{\circ} \times 0.5^{\circ}$ grid box per track). For TCCON measurements, we use all good quality data.

\subsection{Top-Down $\mathrm{ACO}_{2}$ Signal}

The top-down estimate of $\Delta \mathrm{X}_{\mathrm{CO}_{2}}\left(\Delta \mathrm{X}_{\mathrm{CO}_{2}}\right.$ top-down $)$ is calculated based on the data-model difference between OCO-2 and TCCON measurements and simulated $\mathrm{CO}_{2}$ fields based on climatological NEE and ocean fluxes and ODIAC fossil fuel emissions (Oda \& Maksyutov, 2011; Oda et al., 2018).

Climatological NEE and ocean fluxes are generated through $\mathrm{CO}_{2}$ flux inversion analyses as the average over the period 2010-2018. Fluxes over 2010-2014 are taken as the mean GOSAT + surface + TCCON inversion of Byrne, Liu, Lee, et al. (2020). To generate climatological fluxes over 2015-2019, we perform a flux inversion at $4^{\circ} \times 5^{\circ}$ assimilating OCO-2 measurements and surface-based $\mathrm{CO}_{2}$ measurements concurrently and use the identical inversion set-up to Byrne, Liu, Lee, et al. (2020). For surface measurements, we use version 6.0 of the GLOBALVIEW plus package (Masarie et al., 2014; Schuldt et al., 2020). For OCO-2 measurements, we use ACOS b10 land (land glint and land nadir) and ocean glint retrievals aggregated into super-obs at $0.5^{\circ} \times 0.5^{\circ}$ resolution grids following Liu et al. (2017), with the additional requirement that there must be a minimum of three OCO-2 observations within each $0.5^{\circ} \times 0.5^{\circ}$ grid box per track. We use all data that pass the quality flag filter. This 2015-2019 flux inversion is referred to as the "IS + LNLGOG" inversion.

Calculations of the $\Delta \mathrm{X}_{\mathrm{CO}_{2}}$ top-down signal are performed with the one-way nested grid over Australia. First, we generate boundary conditions by performing a simulation at $2^{\circ} \times 2.5^{\circ}$ with regrided optimized NEE and ocean fluxes and prescribed fluxes from the $4^{\circ} \times 5^{\circ}$ flux inversion for 2019-2020. Then we run the nested model with the climatological NEE and ocean fluxes and ODIAC fossil fuel emissions (we impose 2018 ODIAC emissions for 2019 and 2020 based on the availability of data). Simulated $\mathrm{CO}_{2}$ fields are sampled for OCO-2 and TCCON observations from 1 October 2019 through 31 January 2020. Finally, we calculate the $\Delta \mathrm{X}_{\mathrm{CO}_{2}}$ top-down anomaly signal as the data-model mismatch for these simulated observations.

\subsection{NEE Anomaly Estimate}

NEE anomalies ( $\triangle$ NEE) over the 2019-2020 growing season are estimated by combining the constraints on GPP from FluxSat Version 2 (Joiner \& Yoshida, 2020) with the constraints on the net $\mathrm{CO}_{2}$ flux from the top-down $\Delta \mathrm{X}_{\mathrm{CO}_{2}}$ top-down signal and biomass-burning $-\Delta \mathrm{X}_{\mathrm{CO}_{2}}$ вB. The spatial and temporal structure of $\Delta \mathrm{NEE}$ is assumed to be directly proportional to $\Delta \mathrm{GPP}$ from FluxSat, while the magnitude of the $\Delta \mathrm{NEE}$ is inferred from the atmospheric $\Delta \mathrm{X}_{\mathrm{CO}_{2}}$ signal. 
FluxSat estimates GPP based on Nadir BRDF-Adjusted Reflectances (NBAR) from the MODIS MYD43D product (Schaaf et al., 2002). The GPP estimates are calibrated with the FLUXNET 2015 GPP derived from eddy covariance flux measurements at Tier 1 sites (Joiner \& Yoshida, 2020). The native spatiotemporal resolution of FluxSat GPP is daily on a $0.05^{\circ} \times 0.05^{\circ}$ grid. For our analysis, we regrid spatially to $0.1^{\circ} \times 0.1^{\circ}$ while retaining daily temporal resolution. We calculate $\Delta$ GPP from FluxSat as the difference between fluxes for 2019-2020 relative to a 2010-2018 mean.

To estimate $\Delta \mathrm{NEE}$, we assume $\Delta \mathrm{NEE} \propto-\Delta \mathrm{GPP}$. Empirical evidence from the OzFlux eddy covariance network supports this assumption. Li et al. (2017) found that $\Delta$ NEE can be expressed linearly as a function of $\Delta \mathrm{GPP}$ with reasonable accuracy, and obtain the relationships of $\Delta \mathrm{NEE}=-0.24 \Delta \mathrm{GPP}$ for non-forest ecosystems, where anomalies in GPP and respiration are correlated, but $\triangle \mathrm{NEE}=-0.8 \Delta \mathrm{GPP}$ for forest ecosystems, where GPP and respiration do not co-vary. To estimate the magnitude of $\Delta \mathrm{NEE}$, we simulate the OCO-2 observed $\mathrm{X}_{\mathrm{CO}_{2}}$ anomaly signal due to $\Delta \mathrm{GPP}\left(\Delta \mathrm{X}_{\mathrm{CO}_{2}}\right.$ GPP $)$ using the same approach as was used for biomass burning (See Section 3.1.1). We invert a magnitude of $\Delta \mathrm{NEE}$ through regressions of $\Delta \mathrm{X}_{\mathrm{CO}_{2}}$ NEE against an observationally constrained anomaly in $\mathrm{X}_{\mathrm{CO}_{2}}$ :

$$
\Delta \mathrm{X}_{\mathrm{CO}_{2}} \text { NEE }+\beta=-\alpha \times \Delta \mathrm{X}_{\mathrm{CO}_{2}} \text { GPP }+\beta=\Delta \mathrm{X}_{\mathrm{CO}_{2} \text { top-down }}-\Delta \mathrm{X}_{\mathrm{CO}_{2}} \text { BB } .
$$

Note that $\beta$ is included to account for possible small residual biases from the observations or model. Initially, we attempted a multivariate regression to solve this for forest and non-forest $\Delta \mathrm{X}_{\mathrm{CO}_{2}}$ NEE individually but recovered unrealistic negative coefficients for forests. The $\Delta \mathrm{X}_{\mathrm{CO}_{2}}$ NEE for forests is relatively small and may be impacted by errors in biomass burning emissions and transport, potentially limiting our ability to differentiate forest and non-forest $\triangle$ NEE. To avoid these unphysical values, we prescribe the ratio of $\Delta$ NEE between forest and non-forest ecosystems. Following from Li et al. (2017), we perform one set of regressions using,

$$
\Delta \mathrm{NEE}_{\text {total }}=-\alpha\left[0.24 \Delta \mathrm{GPP}_{\text {non-forest }}+0.8 \Delta \mathrm{GPP}_{\text {forest }}\right] \text {. }
$$

However, due to the large $\mathrm{CO}_{2}$ biomass burning emissions over this event, it is possible that $\Delta \mathrm{NEE}$ and $\Delta \mathrm{GPP}$ may diverge from this relationship. Therefore, we also perform a second set of regressions using the relationship:

$$
\Delta \mathrm{NEE}_{\text {total }}=-\alpha\left[\Delta \mathrm{GPP}_{\text {non-forest }}+\Delta \mathrm{GPP}_{\text {forest }}\right] .
$$

We perform a series of linear regressions using Equation 1 to estimate " $\alpha$," the parameter that relates $\Delta$ NEE and $\Delta$ GPP. This regression is performed a total of 32 times by varying the emission height of biomass burning emissions between the surface and injection height, the posterior biomass burning emissions estimated by the eight TROPOMI flux inversions, and the parameterization relating forest and non-forest $\triangle$ NEE using Equations 2 and 3. Table 2 shows the statistics of $\alpha$ for these 32 regressions. The best estimate of $\alpha$ is then calculated as the mean of the truncated distribution of the $32 \alpha$ values, with the largest and smallest two values removed, and the range of the truncated distribution is taken as the uncertainty. This gives an $\alpha$ of $0.41(0.23-0.66)$ for forest ecosystems, which is half the value of $\mathrm{Li}$ et al. (2017), and $0.23(0.13-0.35)$ for non-forest ecosystem, which is almost identical to the value of $\mathrm{Li}$ et al. (2017). These $\alpha$ values are applied to estimate $\Delta$ NEE over the entire growing season.

A comparison of $\Delta \mathrm{X}_{\mathrm{CO}_{2}}$ top-down and the simulated $\Delta \mathrm{X}_{\mathrm{CO}_{2}}$ GPP $+\Delta \mathrm{X}_{\mathrm{CO}_{2}}$ BB signal for TCCON and OCO-2 measurements is shown in the Figures S6 and S7 in Supporting Information S1. The flux estimates found here are generally consistent with these top-down data sets, although there is considerable scatter between different TCCON sites and OCO-2 viewing modes. Data-model mismatches for individual retrievals are strongly impacted by retrieval errors and model errors in simulating the observations, however, aggregating to $0.2 \mathrm{ppm}$ intervals in the flux signal reveals strong positive correlations $\left(R^{2}>0.9\right.$, Figure S6 in Supporting Information S1). Similarly, simulated boundary layer $\mathrm{CO}_{2}$ at $\mathrm{CGO}$ and LAU shows improved agreement with the measurements when the flux anomalies are included, while results at BHD are mixed (Table S6 in Supporting Information S1).

\section{Carbon Cycle Anomalies Over the 2019-2020 Growing Season}

The climate anomalies over the 2019-2020 growing season can be partitioned into two phases. Warm-dry conditions dominated the region during the austral spring and early summer (October through January), when there were a number of biomass burning events, primarily in the forested regions. This was followed by a cooler-wetter 

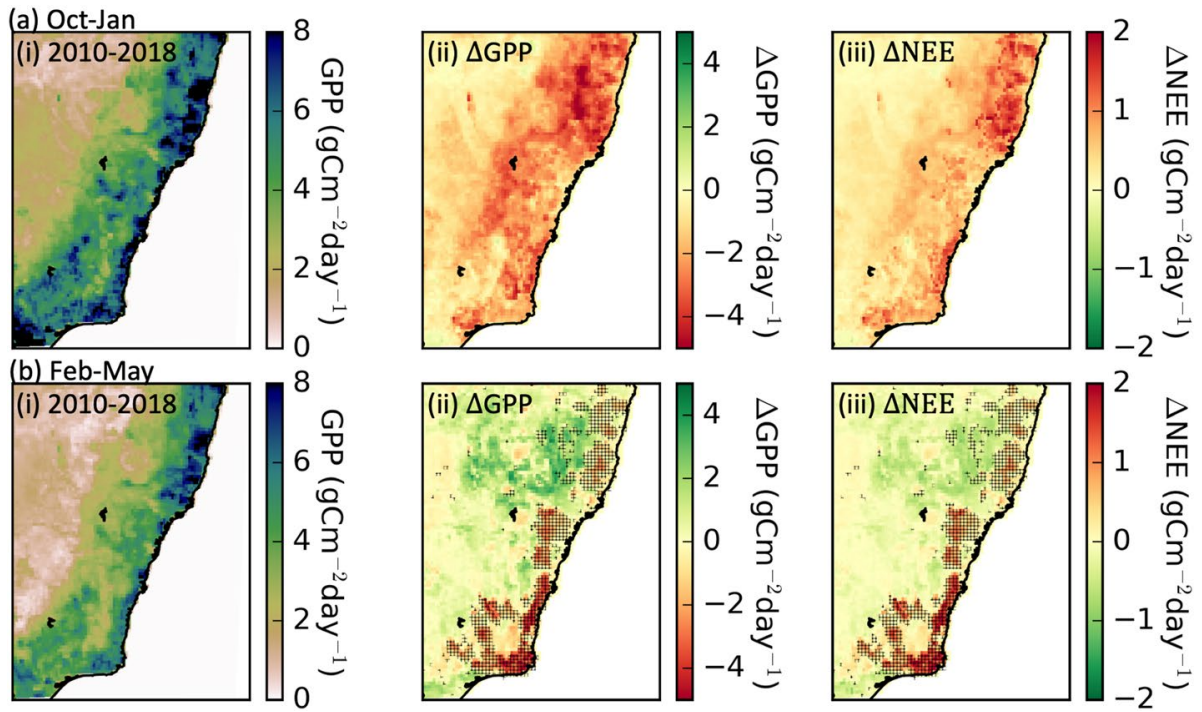

Figure 3. (a) October-January and (b) February-May maps of (i) 2010-2018 mean gross primary productivity (GPP), (ii) $\Delta$ GPP (2019-2020 GPP minus 2010-2018 mean GPP) and (iii) mean estimate of $\Delta$ NEE. Hatching shows locations of bushfires during the 2019-2020 growing season.

period during February through May (Figures 1a and 1b). Video 2 shows the evolution of $\Delta$ NEE and biomass burning over the 2019-2020 growing season. During the warm-dry phase, GPP was suppressed across the region, falling below the range of observed GPP over the $2010-2018$ period $\left(2.0 \mathrm{gC} \mathrm{m}^{-2}\right.$ day $^{-1}$ for October-January 2019-2020 vs. 3.0-4.3 gC m ${ }^{-2}$ day $^{-1}$ over 2010-2018). Suppression of productivity occurred uniformly across southeast Australia during October-January (Figure 3), impacting both forest and non-forest ecosystems. This is followed by a large-scale recovery in GPP to above average values during February-May, when cooler-wetter conditions dominate. This recovery was relatively uniform across the region with the exception of burned areas (indicated by hatching in Figure 3), which show suppression of GPP during February-May that is similar to October-January.

Figure 4 shows the timeseries of $\Delta$ GPP for forest and combined non-forest ecosystems (includes cropland, grassland, shrubland, and savanna ecosystems) over southeast Australia (145.5-154.5 E and 28.5-38.5 S). We divide forests into burned and unburned regions using a threshold of $50 \mathrm{gC} \mathrm{m}^{-2}$ of biomass burning emissions over the 2019-2020 growing season for each $0.1^{\circ} \times 0.1^{\circ}$ grid cell. For non-forested regions, GPP was suppressed during October-January ( $54 \%$ below mean), but rapidly recovered to above average when cooler-wetter conditions dominate (33\% above mean for February-May). In the unburned forested regions, GPP was suppressed during October-January (23\% below mean), with a partial recovery during February-May ( $8 \%$ below mean). In contrast, the burned forests showed a larger reduction in GPP during October-January (37\% below mean) that persisted throughout February-May (31\% below mean). Similar reductions are found for MODIS near-infrared reflectance of terrestrial vegetation $\left(\mathrm{NIR}_{\mathrm{V}}\right)$ and solar induced fluorescence (SIF) measurements from TROPOMI and OCO2 for these vegetation types (see Text S3 and Figure S5 in Supporting Information S1). The similar reduction in $\mathrm{NIR}_{\mathrm{V}}$ suggest that structural changes in vegetation are partially responsible for the reductions in GPP (He et al., 2020; Y. Sun et al., 2015; Yoshida et al., 2015), and are consistent with site level observations of foliar death in eucalypt forests during 2019-2020 (Nolan et al., 2021). In total, $166 \mathrm{TgC}$ (range: 113-236 TgC) of CO was released through biomass burning and $33 \mathrm{TgC}$ (range: 19-52 $\mathrm{TgC}$ ) was released due to anomalies in NEE over October-May (Table 3).

\section{Impact of 2019-2020 Anomalies on the Regional Carbon Budget}

To contextualize the carbon loss over the 2019-2020 growing season, it is useful to compare this period to the long-term mean. Here, we compare the estimated net biosphere exchange (NBE, sum of NEE and biomass burning) for 2019-2020 relative to $\mathrm{CO}_{2}$ flux inversions spanning the 2010-2019 growing seasons. For simplicity, we will refer to growing seasons as $Y_{1} / Y_{2}$ (e.g., "19/20"), which encompass July of YY through June of YY ${ }_{2}$. 


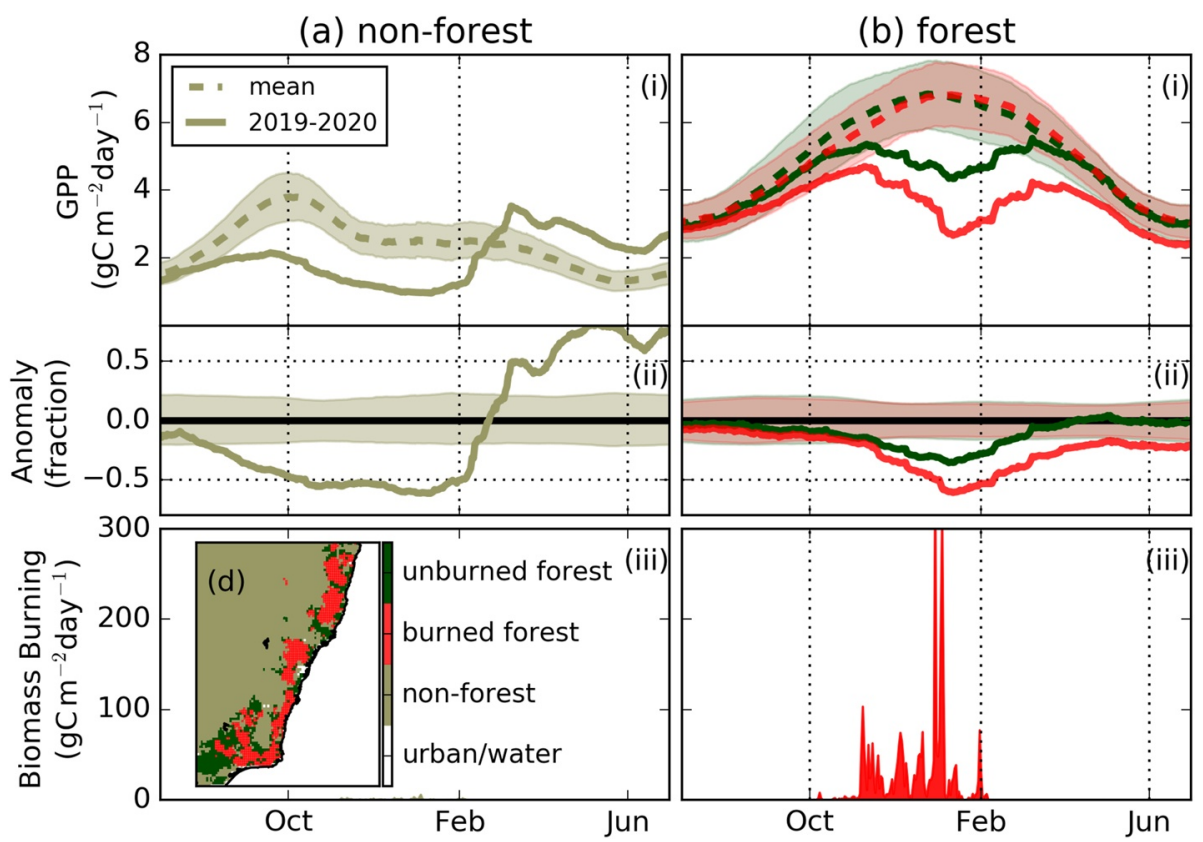

Figure 4. Timeseries of (i) gross primary productivity (GPP), (ii) anomaly in GPP as a fraction of the mean and (iii) biomass burning emissions for (a) non-forest (combined Cropland/Grassland/Savanna/Shrubland) and (b) unburned and burned forest. (d) The spatial extent of non-forest, and burned and unburned forest over southeast Australia (145.5-154.5 E and 28.5-38.5 S).

We examine annual net NBE from the "GOSAT + surface + TCCON" flux inversion of Byrne, Liu, Lee, et al. (2020) (spanning 2010-2015) and the IS + LNLGOG inversion (spanning 2015-2019) described in Section 3.2. Figure 5 shows NBE estimates for southeast Australia over the period 10/11 through 19/20. We find that the magnitude of the $19 / 20 \mathrm{NBE}$ anomaly (mean: $186 \mathrm{TgC} \mathrm{year}^{-1}$, range: 118 to $275 \mathrm{TgC}$ year $^{-1}$ ) significantly exceeds NBE variability over the $10 / 11$ to $18 / 19$ period, confirming the extreme magnitude of this event. The mean annual net NBE sink over 10/11-18/19 is found to be $-9.5 \mathrm{TgC} \mathrm{year}{ }^{-1}$ (range: -16.1 to $-3.4 \mathrm{TgC} \mathrm{year}^{-1}$ ). However, this mean value is a small residual of considerable inter-annual variations (standard deviation of 40 $\mathrm{TgC}$ year $^{-1}$ ), ranging from sink of $-73 \mathrm{TgC}_{\text {year }}{ }^{-1}$ (range: -114 to $-41 \mathrm{TgC}_{\text {year }}{ }^{-1}$ ) in $10 / 11$, driven by a strong La Niña (Poulter et al., 2014), to a source of $57 \mathrm{TgC} \mathrm{year}^{-1}$ (range: 28 to $99 \mathrm{TgC} \mathrm{year}^{-1}$ ) during the 18/19 drought. The magnitude of interannual variations in NBE are independently confirmed by FluxSat-based $\Delta$ NEE (calculated using the regressions from Section 3.3).

Interannual variations in $\mathrm{NBE}$ are found to be closely associated with climate variability. Strong correlations are obtained with soil temperature and moisture for the flux inversions $\left(R^{2}=0.69 / 0.69\right.$ for temp/moist $)$ and FluxSat-based $\Delta$ NBE $\left(R^{2}=0.60 / 0.87\right.$ for temp/moist). We further examine the relationship between climate variability and uptake over the 18 year period covering 01/02-18/19 for both forests and non-forests with FluxSat GPP (Figure S8 in Supporting Information S1). Over this longer period, we find that soil moisture variability is strongly correlated with variability in FluxSat GPP for forests $\left(R^{2}=0.77\right)$ and non-forests $\left(R^{2}=0.88\right)$. However, soil temperature is not correlated with GPP for forests $\left(R^{2}=0.06\right)$ and moderately correlated with non-forests $\left(R^{2}=0.57\right)$, suggesting that moisture availability is the primary driver of interannual variations in productivity.

This relationship between carbon uptake and climate variability has significant implications for the recovery of these ecosystems. The rate at which the 19/20 carbon loss will be re-absorbed may depend strongly on climate variability and change. Based on the mean NBE estimate of $-9.5 \mathrm{TgC}_{\text {year }}^{-1}$ (range: -16.1 to $-3.4 \mathrm{TgC}_{\text {year }}^{-1}$ ) over 10/11 to 18/19, we would expect an anomalous carbon release of $199 \mathrm{TgC}_{\text {year }}{ }^{-1}$ (range: 131-288 $\mathrm{TgC}$ year $^{-1}$ ) to be recovered in $\sim 21$ years (range: $8-85$ years). However, having ideal cool-wet conditions like 10/11 could shorten this to six years, while hot-dry conditions could prevent a full recovery indefinitely. This highlights the importance of both quantifying the sensitivity of these ecosystems to climate variability, and accurately projecting regional climate changes for predicting the recovery of these ecosystems. 

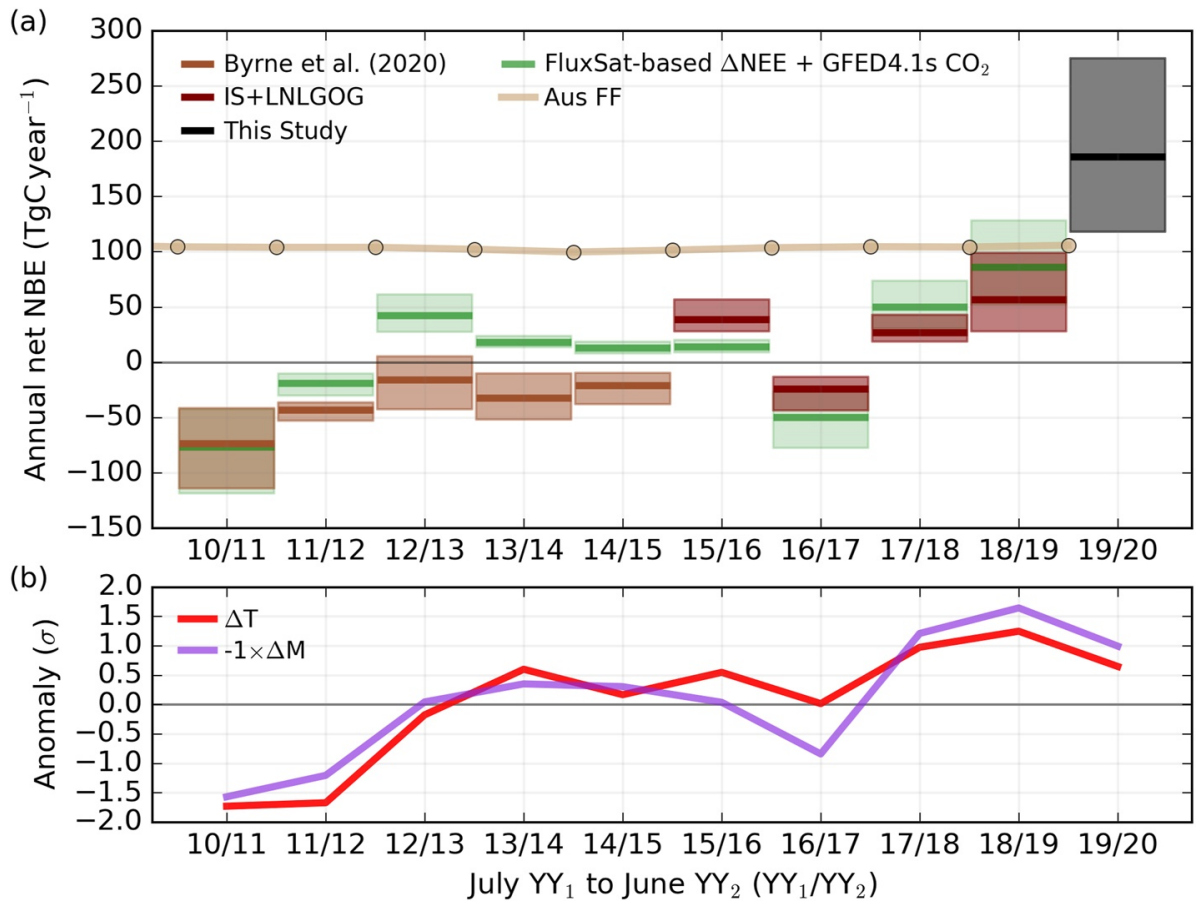

Figure 5. (a) Annual (July-June) net biosphere exchange (NBE) from 10/11 to 19/20 over southeast Australia (142.5-157.5 E and 28-40 S). Flux inversion NBE results are shown for Byrne, Liu, Lee, et al. (2020) (spanning 10/11 to 14/15) and IS + LNLGOG (spanning 15/16 to 18/19), where the solid line shows the mean and the spread shows the range of estimates obtained using three different priors. FluxSat-based NBE anomalies also shown, and are based on the regressions presented in Section 3.3. For comparison, the International Energy Agency (IEA) $\mathrm{CO}_{2}$ emissions from fossil fuel combustion for all of Australia are also plotted (IEA. 2020. $\mathrm{CO}_{2}$ Emissions from Fuel Combustion. All rights reserved.). (b) Anomalies of ERA5 soil temperature and soil moisture (standard deviations) over southeast Australia relative to a reference period from 10/11 to $18 / 19$.

\section{Discussion}

\subsection{Comparison of Biomass Burning Estimates With Other Studies}

Most previous estimates of the 2019-2020 Australian biomass burning $\mathrm{CO}_{2}$ emissions have been derived using bottom-up methods. Most of these estimates are based on burned area, wherein trace gas emissions are derived from space-based burned area measurements using estimates of fire severity, type of vegetation, mass of fuel, and trace gas emission factors (Australian Government Department of Industry \& Resources, 2020; D. M. J. S. Bowman, Williamson, Price, et al., 2020; Shiraishi \& Hirata, 2021). In addition, GFAS uses an alternative bottom-up approach by estimating emissions based on MODIS fire radiative power observations and trace gas emission factors.

The emission estimates calculated in this study are "top-down," in that they are based on observations of the emitted trace gases in the atmosphere. Thus, the different approaches are complementary, and consistency between top-down and bottom-up estimates provides increased confidence in emission estimates. Our estimate of $\mathrm{CO}_{2}$ emissions overlaps with all existing burned-area-based estimates of biomass burning $\mathrm{CO}_{2}$ over southeast Australia (Table 4), providing increased confidence in these estimates. However, our estimated range suggests larger emissions than provided by the GFAS radiative-power-based method, suggesting the GFAS underestimates biomass burning over southeast Australia during 2019-2020. A similar top-down estimate of biomass burning $\mathrm{CO}_{2}$ emissions was reported by van der Velde et al. (2021), and agrees well with the estimates reported here.

\subsection{Implications for Southeast Australia}

The 2019-2020 carbon loss of $199 \mathrm{TgC}$ (range: 131-288 TgC) significantly exceeds annual $\mathrm{CO}_{2}$ flux anomalies of any year since 2010 ( $\sim 5 \sigma$ anomaly) and exceeds total annual Australian $\mathrm{CO}_{2}$ emissions from fossil fuel 
Table 1

Flux Inversion Set-Up for the Eight Nested TROPOMI CO Flux Inversions

\begin{tabular}{lccl}
\hline Inversion & Prior BB emissions & Boundary conditions & Optimized fluxes \\
\hline 1 & GFED4.1s & Optimized & Mean and diurnal \\
2 & GFED4.1s & Optimized & Mean \\
3 & GFED4.1s & opt $+10 \mathrm{ppb}$ & Mean and diurnal \\
4 & GFED4.1s & opt $+10 \mathrm{ppb}$ & Mean \\
5 & GFASv1.2 & Optimized & Mean and diurnal \\
6 & GFASv1.2 & Optimized & Mean \\
7 & GFASv1.2 & opt $+10 \mathrm{ppb}$ & Mean and diurnal \\
8 & GFASv1.2 & opt $+10 \mathrm{ppb}$ & Mean \\
\hline
\end{tabular}

Note. GFED4.1s, Global Fire Emissions Database version 4. combustion (2010-2019 average of $104 \mathrm{TgC}_{\text {year }}{ }^{-1}$ ). This demonstrates the impact that extreme events can have on the regional carbon budget, and suggests changes in the frequency of extreme heat, fire weather and drought could have a strong impact on the regional carbon balance.

During the study period, there was a robust recovery for unburned ecosystems, suggesting that drought- and heat-induced carbon losses over southeast Australia will be rapidly re-absorbed. This is consistent with recent modeling work suggesting resilience to drought in southeast Australian forests (De Kauwe et al., 2020). However, this rapid recovery may be unusual, due to heavy rainfall and below average temperatures during the autumn, which strongly modulate productivity in dryland ecosystems (Haverd et al., 2017; Huxman et al., 2004). Furthermore, there may be drought-induced damages to these ecosystems that are not captured in this analysis, such as drought-induced tree mortality, which has the potential to impact species and biomass composition (Batllori et al., 2020; Burton et al., 2021; Fensham et al., 2019). Recovery in burned ecosystems was much more muted, consistent with major structural damage, preventing a rapid recovery when favorable conditions return.

For the years ahead, the speed and extent of carbon uptake will depend strongly on the climate conditions. The top-down 2010-2019 mean annual sink of $-9.5 \mathrm{TgC} \mathrm{year}^{-1}$ (range: -16.1 to $-3.4 \mathrm{TgC}_{\text {year }}{ }^{-1}$ ) suggests that a full recovery of carbon pools will take 21 years (range: 8-85 years). However, the regional net annual flux showed large interannual variations closely linked with variability in temperature and moisture, with cooler-wetter years being associated with increased uptake. This is consistent with site-level observations showing that rainfall is

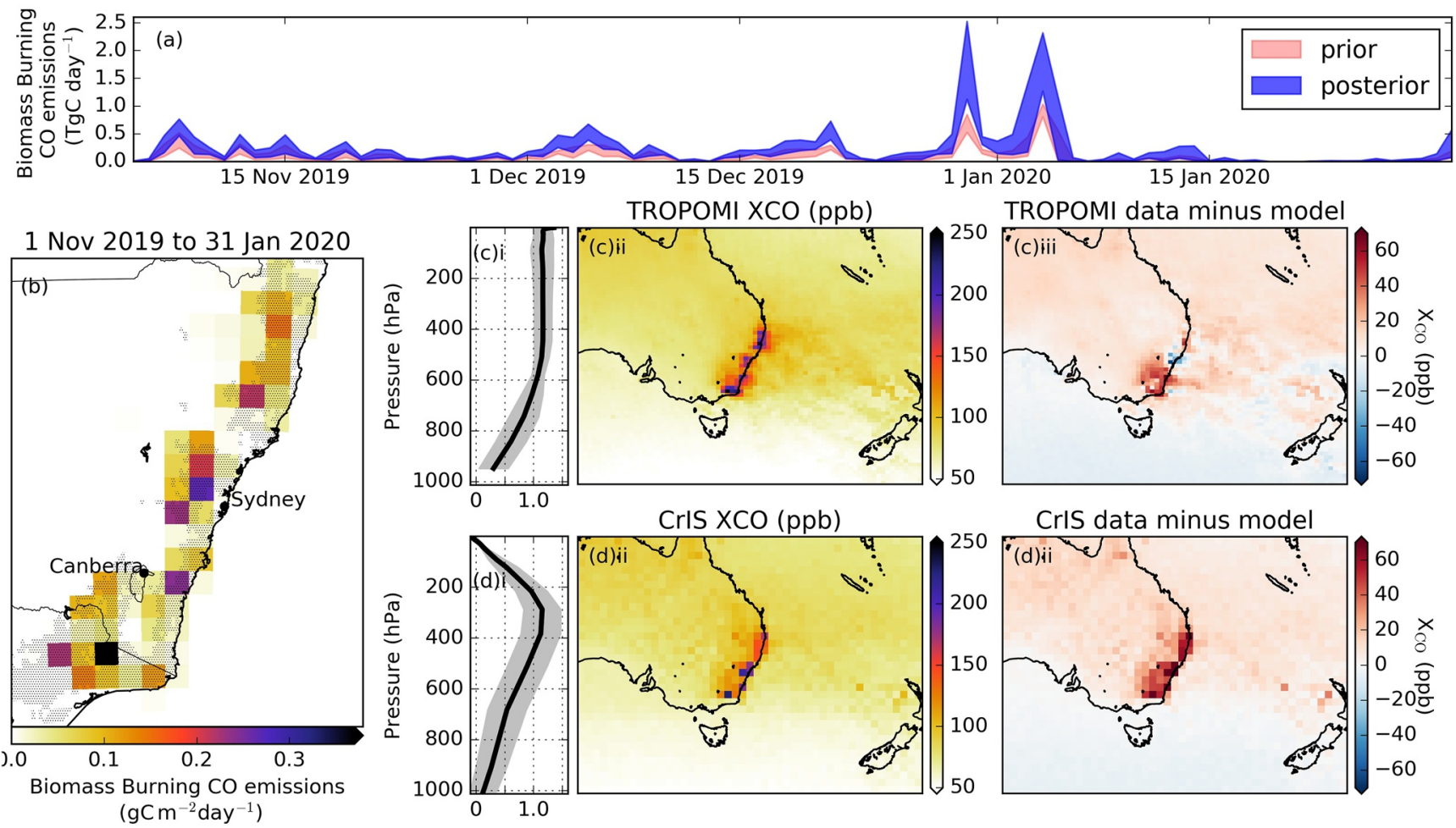

Video 1. (a) Timeseries showing the range of prior (red) and posterior (blue) biomass burning CO emissions over southeast Australia. (b) Mean posterior biomass burning emissions at $0.5^{\circ} \times 0.625^{\circ}$ spatial resolution. Hatching indicates the locations of forested areas. (c) TROPOspheric Monitoring Instrument (i) mean $\mathrm{X}_{\mathrm{CO}}$ column averaging kernel, (ii) mean $\mathrm{X}_{\mathrm{CO}}$, and (iii) posterior data-model mismatch at $0.5^{\circ} \times 0.625^{\circ}$ spatial resolution. (d) CrIS (i) mean $\mathrm{X}_{\mathrm{CO}}$ column averaging kernel, (ii) mean $\mathrm{X}_{\mathrm{CO}}$ and (iii) posterior data-model mismatch at $1.0^{\circ} \times 1.0^{\circ}$ spatial resolution. Video content can be viewed at https://onlinelibrary.wiley.com/ doi/10.1029/2021AV000469. 
Table 2

Coefficients " $\alpha$ " Obtained by Linear Regressions That Relates $\triangle N E E$ and $\triangle G P P$ Through the Relationship $\Delta N E E=-\alpha \Delta G P P$

\begin{tabular}{lcccc}
\hline & & Forest $\alpha$ & & Non-forest $\alpha$ \\
\cline { 3 - 4 } Emission height & $\begin{array}{c}\text { Forest/non-forest } \\
\text { parameterization }\end{array}$ & Median (range) & Median (range) \\
\hline Injection height & $0.24 \mathrm{~N}+0.8 \mathrm{~F}$ & $0.52(0.33-1.15)$ & $0.16(0.10-0.35)$ \\
Injection height & $\mathrm{N}+\mathrm{F}$ & $0.26(0.21-0.42)$ & $0.26(0.21-0.42)$ \\
Surface & $0.24 \mathrm{~N}+0.8 \mathrm{~F}$ & $0.59(0.42-0.66)$ & $0.18(0.12-0.20)$ \\
Surface & $\mathrm{N}+\mathrm{F}$ & $0.31(0.23-0.32)$ & $0.31(0.23-0.32)$ \\
\hline & & Mean (range) & Mean (range) \\
\hline All (truncated) & All (truncated) & $0.41(0.23-0.66)$ & $0.23(0.13-0.35)$ \\
\hline
\end{tabular}

Note. The median and range of $\alpha$ are given for regressions using the eight posterior biomass burning estimates for simulations that vary in the emission height and forest/non-forest parameterization. The bottom row gives the mean and range for the truncated distribution of all simulations, wherein we remove largest and smallest two outliers from the 32 simulations performed by varying biomass burning emissions, emission height, and the forest/non-forest parameterization.

an important driver of the rate of biomass recovery (Q. Sun et al., 2020; Volkova et al., 2019). Under cool-wet conditions, similar to the 2010-2011 La Niña event, carbon recovery could be rapid (within a decade). However, if conditions are warm and dry, which are expected to become more frequent with climate change (Abatzoglou et al., 2019; Perkins-Kirkpatrick \& Gibson, 2017), carbon stocks may not be able to recover. Further, possible recurrent fires could act to significantly lengthen the recovery period.

In addition to the carbon sequestration, it is important to consider ecosystem recovery. Severe fires can have legacy impacts on ecosystem function even after carbon stocks have been largely regenerated. Severe fires in Eucalyptus forests have been shown to include persistent changes to canopy structure (Karna et al., 2019), increase tree mortality (Bennett et al., 2016; Etchells et al., 2020) and cause changes in understory composition and structure (D. M. J. S. Bowman et al., 2014; Fairman et al., 2016; Fletcher et al., 2014; Pellegrini et al., 2021). In particular, fire-induced tree mortalities are generally higher in smaller-younger cohorts (Bennett et al., 2016; Bowd et al., 2021). For some species, such as Mountain Ash, 20 years are required to reach maturity and produce

Oct 2019 to May 2020

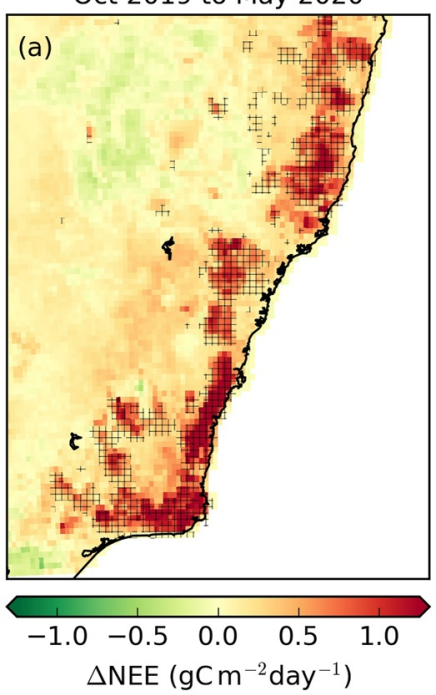

Oct 2019 to May 2020

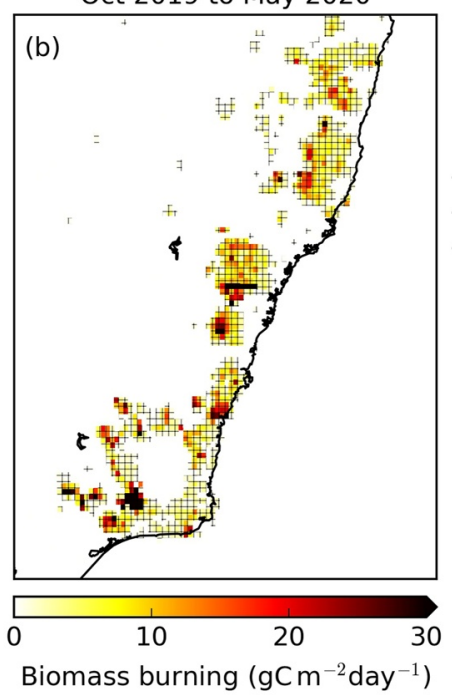

$\triangle \operatorname{NEE}\left(\mathrm{gC} \mathrm{m}^{-2} \mathrm{day}^{-1}\right)$

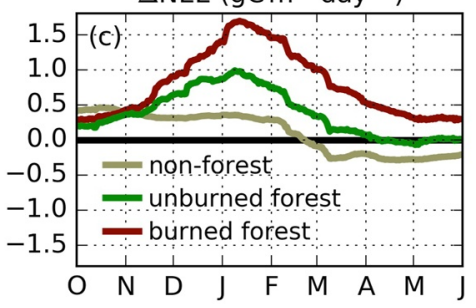

250 Biomass burning $\left(\mathrm{gC} \mathrm{m}^{-2}\right.$ day $\left.^{-1}\right)$

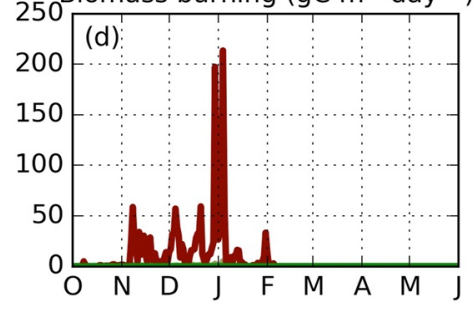

Video 2. Daily (a) $\triangle$ NEE and (b) biomass burning emissions over southeast Australia. Hatching shows burned area. Timeseries of (c) $\triangle$ NEE and (b) biomass burning for (light gray) non-forest, (green) unburned forest, and (red) burned forest areas. Video content can be viewed at https://onlinelibrary.wiley.com/doi/10.1029/2021AV000469. 
Table 3

October-May Net $\mathrm{CO}_{2}$ Fluxes (TgC) Due To Biomass Burning and $\triangle N E E$

Over Southeast Australia

\begin{tabular}{lcccc}
\hline & Non-forest & Burned forest & Unburned forest & All \\
\hline BB & $20(18-23)$ & $146(95-213)$ & 0 & $166(112-235)$ \\
$\Delta$ NEE & $12(7-18)$ & $16(9-26)$ & $5(3-8)$ & $33(19-52)$ \\
Total & $32(24-40)$ & $163(104-239)$ & $5(3-8)$ & $199(131-288)$ \\
\hline
\end{tabular}

viable seeds (Lindenmayer et al., 2021), potentially threatening the survival of these species if subject to recurrent fire for several decades.

Finally, the impact of disturbance and ecosystem recovery should be considered within the context of ongoing climate change. This region is experiencing more frequent extreme heat and fire events (Abram et al., 2020; Bradstock et al., 2014; Sharples et al., 2016), a trend that is expected to continue with climate change (Abatzoglou et al., 2019; Di Virgilio et al., 2019; Dowdy et al., 2019; Herold et al., 2021; Perkins-Kirkpatrick \& Gibson, 2017). Projections of regional trends in drought are less certain. However, several studies suggest drought intensity and frequency may increase in the coming years over much of southeast Australia (Herold et al., 2021; J. Wang et al., 2021; Kirono et al., 2020; Ukkola et al., 2020), with Herold et al. (2021) finding 1-in-20 year droughts may become 1-in-5 year events by 2060-2079.

Trends in climate variability will likely have a number of impacts on the carbon cycle of the region. A major risk for forest ecosystems is recurrent fires during recovery from the previous fires, with studies finding significant negative impacts on ecosystem function for both obligate seeder (D. M. J. S. Bowman et al., 2014) and resprouter-dominated communities (Collins, Hunter, et al., 2021; Fairman et al., 2017). This risk may be compounded by longer recovery periods after fire due to frequent extreme heat and drought events. In particular, if the inter-fire interval decreases below the recovery time, permanent carbon loss will be experienced by these ecosystems, potentially leading to major changes in the ecosystem structure and fire regimes of the region (Boer et al., 2016).

Detecting permanent changes in the regional carbon budget will require sustained monitoring of the regional carbon budget through a combination of expanding top-down constraints (Crisp et al., 2018), as presented in this work, in addition to continued and improved site-level monitoring (D. M. J. S. Bowman, Williamson, Yebra, et al., 2020).

\subsection{Uncertainties in Estimating Carbon Flux}

In this analysis, we have calculated drought-induced NEE anomalies and biomass burning $\mathrm{CO}_{2}$ anomalies over southeast Australia during 2019-2020 that are consistent with observed $\mathrm{X}_{\mathrm{CO}}, \mathrm{X}_{\mathrm{CO}_{2}}$ and FluxSat GPP. Still, there are remaining challenges in quantifying carbon cycle perturbations, leading to large uncertainties in the estimates presented here.

\subsubsection{Model Transport}

Accurate representation of atmospheric transport of $\mathrm{CO}$ and $\mathrm{CO}_{2}$ from biomass burning remains a major challenge (Eastham \& Jacob, 2017). Rapid pyroconvective motions are not well represented in our model simulations. This leads to errors in simulated $\mathrm{X}_{\mathrm{CO}}$ fields relative to the observations and systematic errors in flux inversions. In our analysis, we performed sensitivity analyses by evaluating the posterior $\mathrm{CO}$ fields for emissions released at the surface and at an estimated plume injection height (emitted at up to $6 \mathrm{~km}$ in altitude, Text S1 and Figure S1 in Supporting Information S1), and found that the posterior emissions better matched independent CO observations in both cases. Still, Modeled CrIS $\mathrm{X}_{\mathrm{CO}}$, which are most sensitive to the upper troposphere, showed weak sensitivity to biomass burning emissions despite the fact that biomass burning species were observed in the stratosphere (Hirsch \& Koren, 2021; Khaykin et al., 2020; Schwartz et al., 2020). This suggests that modeled vertical motions are too weak and do not fully capture the vertical structure of biomass burning species produced by strong pyroconvective motions. Such systematic errors are challenging to address, but one possible avenue of future study would be to utilize weak constraint 4D-Var (Stanevich et al., 2019), which would allow for optimizing both surface fluxes and the atmospheric state. Accounting for the total $\mathrm{CO}$ change throughout the column would provide a quantitative assessment of the impact of systematic transport errors on $\mathrm{CO}$ emission estimates. Another avenue of future work could be to improve the 
representation of pyroconvective motions in transport models. As these motions are sub-grid scale for typical chemical transport models, this would most likely require prescribing vertical mass fluxes calculated by a high-resolution cloud resolving model.

\subsection{2. $\mathrm{CO}_{2} / \mathrm{CO}$ Emission Ratio}

To estimate biomass burning $\mathrm{CO}_{2}$ emissions from estimated $\mathrm{CO}$ emissions, the $\mathrm{CO}_{2} / \mathrm{CO}$ emission ratio needs to be precisely and accurately known. However, there is considerable uncertainty in this value, with recent reported values for Australian forests ranging from $8.59 \pm 1.16 \mathrm{gC} \mathrm{gC}^{-1}$ (Paton-Walsh et al., 2014) to $12.65 \pm 2.34 \mathrm{gC}$ $\mathrm{gC}^{-1}$ (Guérette et al., 2018) (Table S7 in Supporting Information S1). We incorporated some of this uncertainty

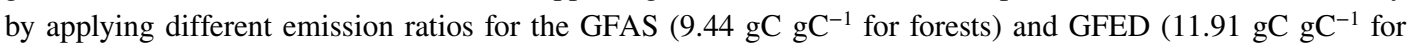
forests) based biomass burning estimates. Comparison of simulated and measured $\mathrm{X}_{\mathrm{CO}_{2}}$ and $\mathrm{X}_{\mathrm{CO}}$ retrievals at Wollongong and Lauder supports the emission ratios employed here (Figure S9 in Supporting Information S1). For Wollongong, we found an observed $\mathrm{X}_{\mathrm{CO}_{2}} / \mathrm{X}_{\mathrm{CO}}$ ratio of $0.014 \mathrm{ppm} \mathrm{ppb}$ (range: $0.011-0.036 \mathrm{ppm} \mathrm{ppb}^{-1}$ ) and a simulated $\mathrm{X}_{\mathrm{CO}_{2}} / \mathrm{X}_{\mathrm{CO}}$ ratio of $0.017 \mathrm{ppm} \mathrm{ppb}^{-1}$ (range: $0.009-0.021 \mathrm{ppm} \mathrm{ppb}^{-1}$ ), while the dynamic range of biomass-burning-impacted measurements at Lauder was not sufficient to provide a strong constraint on the emission ratio (note that $\mathrm{X}_{\mathrm{CO}_{2}} / \mathrm{X}_{\mathrm{CO}}$ ratios are not directly comparable to emission ratios due to chemical loss of $\mathrm{CO}$ ). Still, we acknowledge that uncertainty in the $\mathrm{CO}_{2} / \mathrm{CO}$ emission ratio remains a major challenge in estimating $\mathrm{CO}_{2}$ biomass burning emissions from $\mathrm{CO}$ flux inversion analyses.

\subsubsection{Data Gaps}

It is also notable that the largest biomass burning enhancements of $\mathrm{X}_{\mathrm{CO}_{2}}$ were not observable by OCO-2 or TCCON sites due to the presence of co-emitted aerosols (J. Wang et al., 2020). Rapid deployment of aircraft campaigns that observe the chemical composition of the biomass burning plumes would help mitigate these sampling biases. The serendipitous occurrence of the Atmospheric Carbon and Transport-America (ACT-America) flight campaign during the 2019 Midwest floods provided supporting evidence of the flood-induced $\mathrm{CO}_{2}$ flux anomalies estimated by Yin, Byrne, et al. (2020), resulting in increased confidence in those estimates.

\subsubsection{Estimating $\triangle \mathrm{NEE}$}

Due to atmospheric mixing and the relatively sparse sampling of $\mathrm{X}_{\mathrm{CO}_{2}}$ by OCO-2, it is not possible to fully resolve the spatial and temporal structure in $\triangle$ NEE. Thus, we utilized the spatiotemporal structure of $\Delta$ GPP to predict the spatiotemporal structure of $\Delta \mathrm{NEE}$ for forests and non-forest to regularize the problem. Although, this linear relationship is generally supported by eddy-covariance measurements within Australia (Li et al., 2017), there are likely many cases where this linearity breaks down. We do not account for this source of systematic error in our analysis, suggesting that the uncertainties may be larger and more systematic than estimated here.

\subsubsection{Unaccounted for Carbon Fluxes}

Finally, we note that, we only quantify land-atmosphere $\mathrm{CO}_{2}$ fluxes in this study, and that a full accounting of the carbon stock changes due to this event would need to incorporate lateral carbon fluxes. Intense rainfall following immediately after fire likely increased runoff of ash and debris to waterways, leading to a number of record fish kills in estuarine sites located downstream of burned areas (Silva et al., 2020). Thus, there may have been considerable export of carbon to waterways and the ocean, but this has not been quantified to our knowledge. In addition, we only include estimates of biomass burning emissions of $\mathrm{CO}_{2}$. We estimate an additional $15-29 \mathrm{TgC}$ emitted as $\mathrm{CO}$ from biomass burning.

\section{Conclusions}

Extreme events play a major role in the carbon cycling of ecosystems, but quantifying the impact of these events on the carbon budget remains challenging. Incorporating a variety of space-based observations, we have provided a comprehensive accounting of biosphere-atmosphere $\mathrm{CO}_{2}$ flux anomalies due to drought, heat, and fire over southeast Australia (145.5-154.5 E and 28.5-38.5 S) during the 2019-2020 austral growing season. In total, biomass burning released 113-236 $\mathrm{TgC}$ of $\mathrm{CO}_{2}$ and anomalies in October-May NEE reduced carbon uptake by 19-52 TgC. Carbon losses were found to be most severe in forested regions and were dominated by biomass burning emissions. Unburned forests and non-forest ecosystems recovered to mean or greater productivity when 
cooler-wetter conditions dominated during the late austral summer and autumn, however, primary productivity remained suppressed in burned regions.

The carbon loss over 2019-2020 is found to significantly exceed interannual variability in the regional carbon uptake over 2010-2019 from a set of top-down estimates ( $\sim 5 \sigma$ anomaly), highlighting the extreme nature of this event. In the years to come, these ecosystems are expected to largely recover lost carbon stocks. However, the speed of recovery may be strongly regulated by climate variability and change, with reduced uptake during hot and dry conditions. This has important implications for the future carbon budget of the region. Climate-change-driven increases in the frequency of extreme heat and drought events will increase the recovery period after fires and decrease the inter-fire interval. If the recovery period becomes longer than the inter-fire interval then permanent carbon losses are likely.

This analysis finds that space-based remote sensing of trace gases and MODIS reflectances provide strong constraints on carbon cycle anomalies produced by extreme events. Still, there are remaining challenges that result in significant uncertainties in inferred fluxes. For inferring biomass burning estimates from $\mathrm{X}_{\mathrm{CO}}$ measurements, resolving pyroconvective tracer transport remains a major challenge and source of uncertainty. Aerosols co-emitted with biomass burning $\mathrm{CO}$ and $\mathrm{CO}_{2}$ prevent total-column trace gas retrievals within much of the biomass burning plume. In addition, estimating $\mathrm{CO}_{2}$ emissions from $\mathrm{CO}$ has considerable uncertainty, as does estimating the spatiotemporal structure of $\triangle \mathrm{NEE}$ estimates. Addressing these sources of uncertainty, in addition to expanding spacebased trace gas observations will provide increasingly precise estimates of carbon release from extreme events.

\section{Appendix A: Flux Inversion Configuration}

The nested CO flux inversions are performed over a one-way nested domain of $\left(100^{\circ}-177.5^{\circ} \mathrm{E}\right.$ and $\left.0^{\circ}-60^{\circ} \mathrm{S}\right)$ at $0.5^{\circ} \times 0.625^{\circ}$ spatial resolution. Assimilated TROPOspheric Monitoring Instrument (TROPOMI) $\mathrm{X}_{\mathrm{CO}}$ super-obs are generated by aggregating measurements for each orbit with the quality flag $\geq 0.5$ to the $0.5^{\circ} \times 0.625^{\circ}$ spatial grid. The flux inversions optimize scaling factors to each model gridcell for prior biomass burning emissions from 5 November 2019 through 14 January 2020. Prior biomass burning emissions vary between flux inversions and are listed in Table 1. For the anthropogenic emissions, we combine off-line emission inventories from the Emission Database for Global Atmospheric Research (EDGAR 4.2) global model (Olivier \& Berdowski, 2001) and several regional models including the US Environmental Protection Agency National Emission Inventory for 2008 in North America, the Criteria Air Contaminants inventory for Canada, the Big Bend Regional Aerosol and Visibility Observational Study Emissions Inventory for Mexico (Kuhns et al., 2003), the Cooperative Program for Monitoring and Evaluation of the Long-range Transmission of Air Pollutants in Europe inventory for Europe in 2000 (Vestreng, 2002) and the Streets Asia emissions inventory for 2000 (Streets et al., 2006). Monthly BioFuel emissions are from the EDGAR (Crippa et al., 2016), monthly shipping emissions from the International Comprehensive Ocean-Atmosphere Data Set (C. Wang et al., 2008), and hourly Biogenic emissions from Model of Emissions of Gases and Aerosols from Nature (Guenther et al., 2012).

Boundary conditions for the nested flux inversions are generated by performing a global inversion with GHGF-Flux at $4^{\circ} \times 5^{\circ}$ spatial resolution over the 3-month period from November 2019 through January 2020. The global inversion assimilates TROPOMI $\mathrm{X}_{\mathrm{CO}}$ super-obs (aggregated to $4^{\circ} \times 5^{\circ}$ for measurements with quality flag equal to one) to optimize 14-day scaling factors for prior Global Fire Emissions Database version biomass burning emissions at each grid cell. Other prescribed emissions are identical to the nested flux inversion. Initial conditions for the global flux inversion are obtained from a global MOPITT $\mathrm{X}_{\mathrm{CO}}$ flux inversion. To test the sensitivity of inferred fluxes to the boundary conditions of the nested flux inversions, we generate a second set of boundary conditions that are identical to those from the global TROPOMI flux inversion but have CO increased by $10 \mathrm{ppb}$ at all times and locations.

\section{Conflict of Interest}

The authors declare no conflicts of interest relevant to this study. 


\section{Data Availability Statement}

The gridded daily estimates of $\triangle \mathrm{NEE}$ and biomass burning emissions from this study can be downloaded from (https://doi.org/10.48577/jpl.rrk6-7453). GFED data were downloaded from https://www.globalfiredata.org/. GFAS data were downloaded from https://apps.ecmwf.int/datasets/. GFAS is generated using Copernicus Atmosphere Monitoring Service Information 2020, neither the European Commission nor ECMWF is responsible for any use that may be made of the information it contains. TCCON data were obtained from the TCCON Data Archive, hosted by CaltechDATA (https://tccondata.org). We downloaded version 10 of the ACOS OCO-2 lite files from the $\mathrm{CO}_{2}$ Virtual Science Data Environment (https://co2.jpl.nasa.gov/). OCO-2 data were produced by the OCO-2 project at the Jet Propulsion Laboratory, California Institute of Technology, and obtained from the OCO-2 data archive maintained at the NASA Goddard Earth Science Data and Information Services Center. FluxSat data were downloaded from https://avdc.gsfc.nasa.gov/pub/tmp/FluxSat_GPP/. MODIS land cover data was downloaded from the EOSDIS Land Processes DAAC. ETOPO1 elevation data was downloaded from https://www. ngdc.noaa.gov. ERA5-Land data are obtained from the Climate Data Store (https://cds.climate.copernicus.eu). TROPOMI CO data were downloaded from http://www.tropomi.eu/data-products/carbon-monoxide. CrIS CO is provided by the NASA TRoposperhic Ozone and its Precursors from Earth System Sounding (TROPESS) and available from https://tes.jpl.nasa.gov. MODIS NIRv was calculated from MODIS NBAR measurements (MCD43A4), which were downloaded from the LP DAAC. TROPOMI L2 SIF data were downloaded from ftp:// fluo.gps.caltech.edu/data/tropomi/ungridded/SIF740nm. OCO-2 L2 SIF data are available from the GES DISC (https://disc.gsfc.nasa.gov). BHD CO/CO 2 and LAU CO data were downloaded from the World Data Centre for Greenhouse Gases (https://gaw.kishou.go.jp/). LAU $\mathrm{CO}_{2}$ data were obtained from the site PIs. Paul Krummel, Ray Langenfelds, and Zoe Loh are thanked for supplying the $\mathrm{CGO} \mathrm{CO} / \mathrm{CO}_{2}$ data. Australia fossil fuel combustion statistics were downloaded IEA's $\mathrm{CO}_{2}$ Emissions from Fuel Combustion Highlights: https://www.iea.org/ data-and-statistics/data-product/co2-emissions-from-fuel-combustion-highlights.

B. Byrne was supported by an appointment to the NASA Postdoctoral Program at the Jet Propulsion Laboratory, administered by Universities Space Research Association under contract with the NASA. B. Byrne and J. Liu were supported by the NASA OCO2/3 science team program NNH17ZDA001N-OCO2. $\mathrm{K}$. W. Bowman was supported by the NASA Carbon Monitoring System (CMS) project (NNH16ZDA001N-CMS). J. Joiner was supported by the NASA Making Earth System Data Records for Use in Research Environments (MEaSUREs) and Arctic Boreal Vulnerability Experiment (ABoVE) programs. Y. Yin was partially supported by the NASA ECOSTRESS Science Team Project (80NSSC20K0078). The research carried out at the Jet Propulsion Laboratory, California Institute of Technology, was under a contract with the National Aeronautics and Space Administration. Resources supporting this work were provided by the NASA High-End Computing (HEC) Program through the NASA Advanced Supercomputing (NAS) Division at the Ames Research Center. ODIAC project is supported by the Greenhouse Gas Observing SATellite (GOSAT) project, National Institute for Environmental Studies (NIES), Japan. Wollongong TCCON measurements over the period of this study are supported by the Australian Research Council (ARC) grants DP160101598 and LE0668470, while N. M. Deutscher was supported by an ARC Future Fellowship, FT180100327. The authors would like to thank Tom Oda for guidance on fossil fuel statistics. The authors also thank the editor and reviewers for valuable comments that greatly improved this study.

\section{References}

Abatzoglou, J. T., Williams, A. P., \& Barbero, R. (2019). Global emergence of anthropogenic climate change in fire weather indices. Geophysical Research Letters, 46(1), 326-336. https://doi.org/10.1029/2018g1080959

Abram, N. J., Henley, B. J., Gupta, A. S., Lippmann, T. J., Clarke, H., Dowdy, A. J., et al. (2020). Connections of climate change and variability to large and extreme forest fires in southeast Australia. Communications Earth \& Environment, 2(1), 1-17.

Akagi, S. K., Yokelson, R. J., Wiedinmyer, C., Alvarado, M. J., Reid, J. S., Karl, T., et al. (2011). Emission factors for open and domestic biomass burning for use in atmospheric models. Atmospheric Chemistry and Physics, 11(9), 4039-4072. https://doi.org/10.5194/acp-11-4039-2011

Amante, C., \& Eakins, B. W. (2009). ETOPO1 1 arc-minute global relief model: Procedures, data sources and analysis, NOAA technical memorandum NESDIS NGDC-24. National Geophysical Data Center, NOAA. Retrieved from https://doi.org/10.7289/V5C8276M

Australian Government Department of Industry, Energy, Science, \& Resources. (2020). Estimating greenhouse gas emissions from bushfires in Australia's temperate forests: Focus on 2019-20. Retrieved from https://www.industry.gov.au/sites/default/files/2020-04/estimating-greenhouse-gas-emissions-from-bushfires-in-Australias-temperate-forests-focus-on-2019-20.pdf

Bastos, A., Gouveia, C., Trigo, R., \& Running, S. W. (2014). Analysing the spatio-temporal impacts of the 2003 and 2010 extreme heatwaves on plant productivity in Europe. Biogeosciences, 3421-3435. https://doi.org/10.5194/bg-11-3421-2014

Batllori, E., Lloret, F., Aakala, T., Anderegg, W. R., Aynekulu, E., Bendixsen, D. P., et al. (2020). Forest and woodland replacement patterns following drought-related mortality. Proceedings of the National Academy of Sciences, 117(47), 29720-29729. https://doi.org/10.1073/ pnas.2002314117

Bennett, L. T., Bruce, M. J., MacHunter, J., Kohout, M., Tanase, M. A., \& Aponte, C. (2016). Mortality and recruitment of fire-tolerant eucalypts as influenced by wildfire severity and recent prescribed fire. Forest Ecology and Management, 380, 107-117. https://doi.org/10.1016/j. foreco.2016.08.047

Boer, M. M., Bowman, D. M. J. S., Murphy, B. P., Cary, G. J., Cochrane, M. A., Fensham, R. J., et al. (2016). Future changes in climatic water balance determine potential for transformational shifts in Australian fire regimes. Environmental Research Letters, 11(6), 065002. https://doi. org/10.1088/1748-9326/11/6/065002

Boer, M. M., de Dios, V. R., \& Bradstock, R. A. (2020). Unprecedented burn area of Australian mega forest fires. Nature Climate Change, 10(3), 171-172. https://doi.org/10.1038/s41558-020-0716-1

Borsdorff, T., Aan de Brugh, J., Hu, H., Aben, I., Hasekamp, O., \& Landgraf, J. (2018). Measuring carbon monoxide with TROPOMI: First results and a comparison with ECMWF-IFS analysis data. Geophysical Research Letters, 45(6), 2826-2832. https://doi.org/10.1002/2018gl077045

Bowd, E. J., Blair, D. P., \& Lindenmayer, D. B. (2021). Prior disturbance legacy effects on plant recovery post-high-severity wildfire. Ecosphere, 12(5), e03480. https://doi.org/10.1002/ecs2.3480

Bowman, D. M. J. S. (2000). Australian rainforests: Islands of green in a land of fire. Cambridge University Press.

Bowman, D. M. J. S., Balch, J. K., Artaxo, P., Bond, W. J., Carlson, J. M., Cochrane, M. A., et al. (2009). Fire in the earth system. Science, 324(5926), 481-484. https://doi.org/10.1126/science.1163886

Bowman, D. M. J. S., Murphy, B. P., Neyland, D. L., Williamson, G. J., \& Prior, L. D. (2014). Abrupt fire regime change may cause landscape-wide loss of mature obligate seeder forests. Global Change Biology, 20(3), 1008-1015. https://doi.org/10.1111/gcb.12433

Bowman, D. M. J. S., Williamson, G., Yebra, M., Lizundia-Loiola, J., Pettinari, M. L., Shah, S., et al. (2020). Wildfires: Australia needs national monitoring agency. Nature Publishing Group.

Bowman, D. M. J. S., Williamson, G. J., Gibson, R. K., Bradstock, R. A., \& Keenan, R. J. (2021). The severity and extent of the Australia 2019-20 eucalyptus forest fires are not the legacy of forest management. Nature Ecology \& Evolution, 1-8. 
Bowman, D. M. J. S., Williamson, G. J., Price, O. F., Ndalila, M. N., \& Bradstock, R. A. (2020). Australian forests, megafires and the risk of dwindling carbon stocks. Plant, Cell \& Environment, 44(2), 347-355. https://doi.org/10.1111/pce.13916

Bowman, K. W., Rodgers, C. D., Kulawik, S. S., Worden, J., Sarkissian, E., Osterman, G., et al. (2006). Tropospheric emission spectrometer: Retrieval method and error analysis. IEEE Transactions on Geoscience and Remote Sensing, 44(5), 1297-1307. https://doi.org/10.1109/ tgrs.2006.871234

Bradstock, R., Penman, T., Boer, M., Price, O., \& Clarke, H. (2014). Divergent responses of fire to recent warming and drying across South-Eastern Australia. Global Change Biology, 20(5), 1412-1428. https://doi.org/10.1111/gcb.12449

Bureau of Meteorology. (2020). Annual climate statement 2019. Retrieved from http://www.bom.gov.au/climate/current/annual/ aus/\#tabs=Overview

Burrows, G. (2002). Epicormic strand structure in Angophora, Eucalyptus and Lophostemon (Myrtaceae): Implications for fire resistance and recovery. New Phytologist, 111-131. https://doi.org/10.1046/j.0028-646x.2001.00299.x

Burton, J. E., Bennett, L. T., Kasel, S., Nitschke, C. R., Tanase, M. A., Fairman, T. A., et al. (2021). Fire, drought and productivity as drivers of dead wood biomass in eucalypt forests of South-Eastern Australia. Forest Ecology and Management, 482, 118859. https://doi.org/10.1016/j. foreco.2020.118859

Byrne, B., Jones, D. B. A., Strong, K., Polavarapu, S. M., Harper, A. B., Baker, D. F., \& Maksyutov, S. (2019). On what scales can GOSAT flux inversions constrain anomalies in terrestrial ecosystems? Atmospheric Chemistry and Physics, 19(20), 13017-13035. https://doi.org/10.5194/ acp-19-13017-2019

Byrne, B., Liu, J., Bloom, A. A., Bowman, K. W., Butterfield, Z., Joiner, J., et al. (2020). Contrasting regional carbon cycle responses to seasonal climate anomalies across the east-west divide of temperate North America. Global Biogeochemical Cycles, 34, e2020GB006598. https://doi. org/10.1029/2020GB006598

Byrne, B., Liu, J., Lee, M., Baker, I. T., Bowman, K. W., Deutscher, N. M., et al. (2020). Improved constraints on northern extratropical CO, fluxes obtained by combining surface-based and space-based atmospheric $\mathrm{CO}_{2}$ measurements. Journal of Geophysical Research: Atmosphere, 125. https://doi.org/10.1029/2019JD032029

Ciais, P., Reichstein, M., Viovy, N., Granier, A., Ogée, J., Allard, V., et al. (2005). Europe-wide reduction in primary productivity caused by the heat and drought in 2003. Nature, 437(7058), 529-533. https://doi.org/10.1038/nature03972

Collins, L., Bradstock, R. A., Clarke, H., Clarke, M. F., Nolan, R. H., \& Penman, T. D. (2021). The 2019/2020 mega-fires exposed Australian ecosystems to an unprecedented extent of high-severity fire. Environmental Research Letters, 16(4), 044029. https://doi.org/10.1088/1748-9326/ abeb9e

Collins, L., Hunter, A., McColl-Gausden, S., Penman, T. D., \& Zylstra, P. (2021). The effect of antecedent fire severity on reburn severity and fuel structure in a resprouting eucalypt forest in Victoria, Australia. Forests, 12(4), 450. https://doi.org/10.3390/f12040450

Crippa, M., Janssens-Maenhout, G., Dentener, F., Guizzardi, D., Sindelarova, K., Muntean, M., et al. (2016). Forty years of improvements in European air quality: Regional policy-industry interactions with global impacts. Atmospheric Chemistry and Physics, 16(6), 3825-3841. https:// doi.org/10.5194/acp-16-3825-2016

Crisp, D., Meijer, Y., Munro, R., Bowman, K., Baker, D., Chevallier, F., et al. (2018). A constellation architecture for monitoring carbon dioxide and methane from space. https://ceos.org/document_management/Virtual_Constellations/ACC/Documents/CEOS_AC-VC_GHG_White_Paper_Version_1_20181009.pdf

Crisp, D., Pollock, H. R., Rosenberg, R., Chapsky, L., Lee, R. A. M., Oyafuso, F. A., et al. (2017). The on-orbit performance of the Orbiting Carbon Observatory-2 (OCO-2) instrument and its radiometrically calibrated products. Atmospheric Measurement Techniques, 10(1), 59-81. https://doi.org/10.5194/amt-10-59-2017

Deb, P., Moradkhani, H., Abbaszadeh, P., Kiem, A. S., Engström, J., Keellings, D., \& Sharma, A. (2020). Causes of the widespread 2019-2020 Australian bushfire season. Earth's Future, 8, e2020EF001671. https://doi.org/10.1029/2020EF001671

De Boeck, H. J., Dreesen, F. E., Janssens, I. A., \& Nijs, I. (2011). Whole-system responses of experimental plant communities to climate extremes imposed in different seasons. New Phytologist, 189(3), 806-817. https://doi.org/10.1111/j.1469-8137.2010.03515.x

De Kauwe, M. G., Medlyn, B. E., Ukkola, A. M., Mu, M., Sabot, M. E., Pitman, A. J., et al. (2020). Identifying areas at risk of drought-induced tree mortality across South-Eastern Australia. Global Change Biology, 26(10), 5716-5733. https://doi.org/10.1111/gcb.15215

Denton, E. M., Dietrich, J. D., Smith, M. D., \& Knapp, A. K. (2017). Drought timing differentially affects above-and belowground productivity in a mesic grassland. Plant Ecology, 218(3), 317-328. https://doi.org/10.1007/s11258-016-0690-x

Di Giuseppe, F., Rémy, S., Pappenberger, F., \& Wetterhall, F. (2018). Using the Fire Weather Index (FWI) to improve the estimation of fire emissions from fire radiative power (FRP) observations. Atmospheric Chemistry and Physics, 18(8), 5359-5370. https://doi.org/10.5194/ acp-18-5359-2018

Di Virgilio, G., Evans, J. P., Blake, S. A., Armstrong, M., Dowdy, A. J., Sharples, J., \& McRae, R. (2019). Climate change increases the potential for extreme wildfires. Geophysical Research Letters, 46(14), 8517-8526. https://doi.org/10.1029/2019g1083699

Dowdy, A. J., Ye, H., Pepler, A., Thatcher, M., Osbrough, S. L., Evans, J. P., et al. (2019). Future changes in extreme weather and pyroconvection risk factors for Australian wildfires. Scientific Reports, 9(1), 1-11. https://doi.org/10.1038/s41598-019-46362-x

Eastham, S. D., \& Jacob, D. J. (2017). Limits on the ability of global Eulerian models to resolve intercontinental transport of chemical plumes. Atmospheric Chemistry and Physics, 17(4), 2543-2553. https://doi.org/10.5194/acp-17-2543-2017

Eldering, A., O’Dell, C. W., Wennberg, P. O., Crisp, D., Gunson, M. R., Viatte, C., et al. (2017). The Orbiting Carbon Observatory-2: First 18 months of science data products. Atmospheric Measurement Techniques, 10(2), 549-563. https://doi.org/10.5194/amt-10-549-2017

Etchells, H., O’Donnell, A. J., McCaw, W. L., \& Grierson, P. F. (2020). Fire severity impacts on tree mortality and post-fire recruitment in tall eucalypt forests of southwest Australia. Forest Ecology and Management, 459, 117850. https://doi.org/10.1016/j.foreco.2019.117850

Fairman, T. A., Bennett, L. T., Tupper, S., \& Nitschke, C. R. (2017). Frequent wildfires erode tree persistence and alter stand structure and initial composition of a fire-tolerant sub-alpine forest. Journal of Vegetation Science, 28(6), 1151-1165. https://doi.org/10.1111/jvs.12575

Fairman, T. A., Nitschke, C. R., \& Bennett, L. T. (2016). Too much, too soon? A review of the effects of increasing wildfire frequency on tree mortality and regeneration in temperate eucalypt forests. International Journal of Wildland Fire, 25(8), 831-848. https://doi.org/10.1071/ wf15010

Fensham, R. J., Laffineur, B., \& Allen, C. D. (2019). To what extent is drought-induced tree mortality a natural phenomenon? Global Ecology and Biogeography, 28(3), 365-373. https://doi.org/10.1111/geb.12858

Fletcher, M.-S., Wood, S. W., \& Haberle, S. G. (2014). A fire-driven shift from forest to non-forest: Evidence for alternative stable states? Ecology, 95(9), 2504-2513. https://doi.org/10.1890/12-1766.1

Frank, D., Reichstein, M., Bahn, M., Thonicke, K., Frank, D., Mahecha, M. D., et al. (2015). Effects of climate extremes on the terrestrial carbon cycle: Concepts, processes and potential future impacts. Global Change Biology, 21(8), 2861-2880. https://doi.org/10.1111/gcb.12916 
Friedl, M., \& Sulla-Menashe, D. (2015). MCD12C1 MODIS/Terra+ aqua land cover type yearly L3 global 0.05 Deg CMG V006 (Data set). NASA EOSDIS Land Processes DAAC.

Fu, D., Bowman, K. W., Worden, H. M., Natraj, V., Worden, J. R., Yu, S., et al. (2016). High-resolution tropospheric carbon monoxide profiles retrieved from CrIS and TROPOMI. Atmospheric Measurement Techniques, 9(6), 2567-2579. https://doi.org/10.5194/amt-9-2567-2016

Gelaro, R., McCarty, W., Suárez, M. J., Todling, R., Molod, A., Takacs, L., et al. (2017). The Modern-Era Retrospective Analysis for Research and Applications, Version 2 (MERRA-2). Journal of Climate, 30(14), 5419-5454. https://doi.org/10.1175/jcli-d-16-0758.1

Giglio, L., Randerson, J. T., \& Van Der Werf, G. R. (2013). Analysis of daily, monthly, and annual burned area using the fourth-generation global fire emissions database (GFED4). Journal of Geophysical Research: Biogeosciences, 118(1), 317-328. https://doi.org/10.1002/jgrg.20042

Griffith, D. W., Velazco, V. A., Deutscher, N. M., Paton-Walsh, C., Jones, N. B., Wilson, S. R., et al. (2014). TCCON data from Wollongong (AU), release GGG2014.RO. CaltechDATA. https://doi.org/10.14291/tccon.ggg2014.wollongong01.r0/1149291

Guenther, A. B., Jiang, X., Heald, C. L., Sakulyanontvittaya, T., Duhl, T., Emmons, L. K., \& Wang, X. (2012). The model of emissions of gases and aerosols from nature version 2.1 (MEGAN2.1): An extended and updated framework for modeling biogenic emissions. Geoscientific Model Development, 5(6), 1471-1492. https://doi.org/10.5194/gmd-5-1471-2012

Guérette, E.-A., Paton-Walsh, C., Desservettaz, M., Smith, T. E. L., Volkova, L., Weston, C. J., \& Meyer, C. P. (2018). Emissions of trace gases from Australian temperate forest fires: Emission factors and dependence on modified combustion efficiency. Atmospheric Chemistry and Physics, 18(5), 3717-3735. https://doi.org/10.5194/acp-18-3717-2018

Harris, S., \& Lucas, C. (2019). Understanding the variability of Australian fire weather between 1973 and 2017. PLoS One, 14(9), e0222328. https://doi.org/10.1371/journal.pone.0222328

Haverd, V., Ahlström, A., Smith, B., \& Canadell, J. G. (2017). Carbon cycle responses of semi-arid ecosystems to positive asymmetry in rainfall. Global Change Biology, 23(2), 793-800. https://doi.org/10.1111/gcb.13412

He, L., Wood, J. D., Sun, Y., Magney, T., Dutta, D., Köhler, P., et al. (2020). Tracking seasonal and interannual variability in photosynthetic downregulation in response to water stress at a temperate deciduous forest. Journal of Geophysical Research: Biogeosciences, 125(8), e2018JG005002. https://doi.org/10.1029/2018jg005002

Henze, D. K., Hakami, A., \& Seinfeld, J. H. (2007). Development of the adjoint of GEOS-Chem. Atmospheric Chemistry and Physics, 7(9), 2413-2433. https://doi.org/10.5194/acp-7-2413-2007

Herold, N., Downes, S., Gross, M., Ji, F., Nishant, N., Macadam, I., et al. (2021). Projected changes in the frequency of climate extremes over southeast Australia. Environmental Research Communications, 3(1), 011001. https://doi.org/10.1088/2515-7620/abe6b1

Hirsch, E., \& Koren, I. (2021). Record-breaking aerosol levels explained by smoke injection into the stratosphere. Science, 371(6535), 12691274. https://doi.org/10.1126/science.abe1415

Huxman, T. E., Snyder, K. A., Tissue, D., Leffler, A. J., Ogle, K., Pockman, W. T., et al. (2004). Precipitation pulses and carbon fluxes in semiarid and arid ecosystems. Oecologia, 141(2), 254-268. https://doi.org/10.1007/s00442-004-1682-4

Joiner, J., \& Yoshida, Y. (2020). Satellite-based reflectances capture large fraction of variability in global gross primary production (GPP) at weekly time scales. Agricultural and Forest Meteorology, 291, 108092. https://doi.org/10.1016/j.agrformet.2020.108092

Kaiser, J. W., Heil, A., Andreae, M. O., Benedetti, A., Chubarova, N., Jones, L., et al. (2012). Biomass burning emissions estimated with a global fire assimilation system based on observed fire radiative power. Biogeosciences, 9(1), 527-554. https://doi.org/10.5194/bg-9-527-2012

Karna, Y. K., Penman, T. D., Aponte, C., \& Bennett, L. T. (2019). Assessing legacy effects of wildfires on the crown structure of fire-tolerant eucalypt trees using airborne LiDAR data. Remote Sensing, 11(20), 2433. https://doi.org/10.3390/rs11202433

Khaykin, S., Legras, B., Bucci, S., Sellitto, P., Isaksen, L., Tence, F., et al. (2020). The 2019/20 Australian wildfires generated a persistent smokecharged vortex rising up to $35 \mathrm{~km}$ altitude. Communications Earth \& Environment, 1(1), 1-12. https://doi.org/10.1038/s43247-020-00022-5

King, A. D., Pitman, A. J., Henley, B. J., Ukkola, A. M., \& Brown, J. R. (2020). The role of climate variability in Australian drought. Nature Climate Change, 10(3), 177-179. https://doi.org/10.1038/s41558-020-0718-z

Kirono, D. G., Round, V., Heady, C., Chiew, F. H., \& Osbrough, S. (2020). Drought projections for Australia: Updated results and analysis of model simulations. Weather and Climate Extremes, 30, 100280. https://doi.org/10.1016/j.wace.2020.100280

Kuhns, H., Green, M., Etyemezian, V., Watson, J., \& Pitchford, M. (2003). Big bend regional aerosol and visibility observational (BRAVO) study emissions inventory. Report prepared for BRAVO Steering Committee, Desert Research Institute.

Landgraf, J., aan de Brugh, J., Scheepmaker, R., Borsdorff, T., Hu, H., Houweling, S., et al. (2016). Carbon monoxide total column retrievals from TROPOMI shortwave infrared measurements. Atmospheric Measurement Techniques, 9(10), 4955-4975. https://doi.org/10.5194/ amt-9-4955-2016

Langenfelds, R., Francey, R., Pak, B., Steele, L., Lloyd, J., Trudinger, C., \& Allison, C. (2002). Interannual growth rate variations of atmospheric $\mathrm{CO}_{2}$ and its $\delta^{13} \mathrm{C}, \mathrm{H}_{2}, \mathrm{CH}_{4}$, and $\mathrm{CO}$ between 1992 and 1999 linked to biomass burning. Global Biogeochemical Cycles, 16(3), 21-1. https:// doi.org/10.1029/2001gb001466

Li, L., Wang, Y.-P., Beringer, J., Shi, H., Cleverly, J., Cheng, L., et al. (2017). Responses of LAI to rainfall explain contrasting sensitivities to carbon uptake between forest and non-forest ecosystems in Australia. Scientific Reports, 7(1), 1-9. https://doi.org/10.1038/s41598-017-11063-w

Lindenmayer, D., Blair, D., McBurney, L., Banks, S., \& Bowd, E. (2021). Ten years on-a decade of intensive biodiversity research after the 2009 Black Saturday wildfires in Victoria's Mountain Ash forest. Australian Zoologist, 41(2), 220-230. https://doi.org/10.7882/az.2020.041

Liu, J., Bowman, K. W., Lee, M., Henze, D. K., Bousserez, N., Brix, H., et al. (2014). Carbon monitoring system flux estimation and attribution: Impact of ACOS-GOSAT $\mathrm{XCO}_{2}$ sampling on the inference of terrestrial biospheric sources and sinks. Tellus B: Chemical and Physical Meteorology, 66(1), 22486. https://doi.org/10.3402/tellusb.v66.22486

Liu, J., Bowman, K. W., Schimel, D. S., Parazoo, N. C., Jiang, Z., Lee, M., et al. (2017). Contrasting carbon cycle responses of the tropical continents to the 2015-2016 El Niño. Science, 358(6360). https://doi.org/10.1126/science.aam5690

Longo, M., Saatchi, S., Keller, M., Bowman, K. W., Ferraz, A., Moorcroft, P. R., et al. (2020). Impacts of degradation on water, energy, and carbon cycling of the Amazon tropical forests. Journal of Geophysical Research: Biogeosciences, 125(8), e2020JG005677. https://doi. org/10.1029/2020jg005677

Masarie, K., Peters, W., Jacobson, A., \& Tans, P. (2014). ObsPack: A framework for the preparation, delivery, and attribution of atmospheric greenhouse gas measurements. Earth System Science Data, 6(2), 375-384. https://doi.org/10.5194/essd-6-375-2014

Mu, M., Randerson, J., Van der Werf, G., Giglio, L., Kasibhatla, P., Morton, D., et al. (2011). Daily and 3-hourly variability in global fire emissions and consequences for atmospheric model predictions of carbon monoxide. Journal of Geophysical Research: Atmosphere, 116(D24). https://doi.org/10.1029/2011jd016245

Munoz Sabater, J. (2019). Copernicus climate change Service (C3S) climate data store (CDS). https://doi.org/10.24381/cds.68d2bb30

Nolan, R. H., Boer, M. M., Collins, L., Resco de Dios, V., Clarke, H., Jenkins, M., et al. (2020). Causes and consequences of eastern Australia's 2019-20 season of mega-fires. Global Change Biology, 26(3), 1039-1041. https://doi.org/10.1111/gcb.14987 
Nolan, R. H., Gauthey, A., Losso, A., Medlyn, B. E., Smith, R., Chhajed, S. S., et al. (2021). Hydraulic failure and tree size linked with canopy die-back in eucalypt forest during extreme drought. New Phytologist, 230(4), 1354-1365. https://doi.org/10.1111/nph.17298

Oda, T., \& Maksyutov, S. (2011). A very high-resolution $(1 \mathrm{~km} \times 1 \mathrm{~km})$ global fossil fuel $\mathrm{CO}_{2}$ emission inventory derived using a point source database and satellite observations of nighttime lights. Atmospheric Chemistry and Physics, 11(2), 543-556. https://doi.org/10.5194/ acp-11-543-2011

Oda, T., Maksyutov, S., \& Andres, R. J. (2018). The open-source data inventory for anthropogenic CO, version 2016 (ODIAC2016): A global monthly fossil fuel $\mathrm{CO}_{2}$ gridded emissions data product for tracer transport simulations and surface flux inversions. Earth System Science Data, 10(1), 87-107. https://doi.org/10.5194/essd-10-87-2018

Olivier, J., \& Berdowski, J. (2001). Global emissions sources and sinks. The climate system. Lisse, The Netherlands: AA Balkema Publishers/ Swets \& Zeitlinger Publishers $90,5809(255)$.

Paton-Walsh, C., Smith, T., Young, E., Griffith, D. W., \& Guérette, É.-A. (2014). New emission factors for Australian vegetation fires measured using open-path Fourier transform infrared spectroscopy-Part 1: Methods and Australian temperate forest fires. Atmospheric Chemistry and Physics, 14(20), 11313-11333. https://doi.org/10.5194/acp-14-11313-2014

Pellegrini, A. F., Refsland, T., Averill, C., Terrer, C., Staver, A. C., Brockway, D. G., et al. (2021). Decadal changes in fire frequencies shift tree communities and functional traits. Nature Ecology \& Evolution, 5(4), 504-512. https://doi.org/10.1038/s41559-021-01401-7

Perkins-Kirkpatrick, S., \& Gibson, P. (2017). Changes in regional heatwave characteristics as a function of increasing global temperature. Scientific Reports, 7(1), 1-12. https://doi.org/10.1038/s41598-017-12520-2

Pitman, A., Narisma, G., \& McAneney, J. (2007). The impact of climate change on the risk of forest and grassland fires in Australia. Climatic Change, 84(3), 383-401. https://doi.org/10.1007/s10584-007-9243-6

Pollard, D. F., Robinson, J., \& Shiona, H. (2019). TCCON Data from Lauder, New Zealand, 125HR, Release GGG2014R0. CaltechDATA. https:// doi.org/10.14291/tccon.ggg2014.lauder03.R0

Pollard, D. F., Sherlock, V., Robinson, J., Deutscher, N. M., Connor, B., \& Shiona, H. (2017). The total carbon column observing network site description for lauder New Zealand. Earth System Science Data, 9(2), 977-992. https://doi.org/10.5194/essd-9-977-2017

Poulter, B., Frank, D., Ciais, P., Myneni, R. B., Andela, N., Bi, J., et al. (2014). Contribution of semi-arid ecosystems to interannual variability of the global carbon cycle. Nature, 509(7502), 600. https://doi.org/10.1038/nature13376

Randerson, J. T., Chen, Y., Van Der Werf, G., Rogers, B., \& Morton, D. (2012). Global burned area and biomass burning emissions from small fires. Journal of Geophysical Research: Biogeosciences, 117(G4). https://doi.org/10.1029/2012jg002128

Reichstein, M., Ciais, P., Papale, D., Valentini, R., Running, S., Viovy, N., et al. (2007). Reduction of ecosystem productivity and respiration during the European summer 2003 climate anomaly: A joint flux tower, remote sensing and modelling analysis. Global Change Biology, 13(3), 634-651. https://doi.org/10.1111/j.1365-2486.2006.01224.x

Rémy, S., Veira, A., Paugam, R., Sofiev, M., Kaiser, J. W., Marenco, F., et al. (2017). Two global data sets of daily fire emission injection heights since 2003. Atmospheric Chemistry and Physics, 17(4), 2921-2942. https://doi.org/10.5194/acp-17-2921-2017

Schaaf, C. B., Gao, F., Strahler, A. H., Lucht, W., Li, X., Tsang, T., et al. (2002). First operational BRDF, albedo nadir reflectance products from MODIS. Remote Sensing of Environment, 83(1-2), 135-148. https://doi.org/10.1016/s0034-4257(02)00091-3

Schuldt, K., Mund, J., Luijkx, I. T., Jacobson, A. R., Aalto, T., Abshire, J. B., et al. (2020). Multi-laboratory compilation of atmospheric carbon dioxide data for the period 1957-2019; obspack_co2_1_globalviewplus_v6.0_2020-09-11. NOAA Earth System Research Laboratory, Global Monitoring Laboratory. https://doi.org/10.25925/20200903

Schwartz, M. J., Santee, M. L., Pumphrey, H. C., Manney, G. L., Lambert, A., Livesey, N. J., et al. (2020). Australian New Year's PyroCb impact on stratospheric composition. Geophysical Research Letters, 47(24), e2020GL090831. https://doi.org/10.1029/2020g1090831

Sharples, J. J., Cary, G. J., Fox-Hughes, P., Mooney, S., Evans, J. P., Fletcher, M.-S., et al. (2016). Natural hazards in Australia: Extreme bushfire. Climatic Change, 139(1), 85-99. https://doi.org/10.1007/s10584-016-1811-1

Shiraishi, T., \& Hirata, R. (2021). Estimation of carbon dioxide emissions from the megafires of Australia in 2019-2020. Scientific Reports, 11(1), 1-10. https://doi.org/10.1038/s41598-021-87721-x

Silva, L. G., Doyle, K. E., Duffy, D., Humphries, P., Horta, A., \& Baumgartner, L. J. (2020). Mortality events resulting from Australia's catastrophic fires threaten aquatic biota. Global Change Biology, 26(10), 5345-5350. https://doi.org/10.1111/gcb.15282

Sippel, S., Reichstein, M., Ma, X., Mahecha, M. D., Lange, H., Flach, M., \& Frank, D. (2018). Drought, heat, and the carbon cycle: A review. Current Climate Change Reports, 1-21. https://doi.org/10.1007/s40641-018-0103-4

Stanevich, I., Jones, D. B. A., Strong, K., Keller, M., Henze, D. K., Parker, R. J., et al. (2019). Characterizing model errors in chemical transport modelling of methane: Using GOSAT $\mathrm{X}_{\mathrm{CH} 4}$ data with weak constraint four-dimensional variational data assimilation. Atmospheric Chemistry and Physics Discussions, 1-54. https://doi.org/10.5194/acp-2019-786

Stephens, S. L., Agee, J. K., Fule, P. Z., North, M., Romme, W., Swetnam, T., \& Turner, M. G. (2013). Managing forests and fire in changing climates. Science, 342(6154), 41-42. https://doi.org/10.1126/science.1240294

Streets, D. G., Zhang, Q., Wang, L., He, K., Hao, J., Wu, Y., et al. (2006). Revisiting China's CO emissions after the transport and chemical evolution over the pacific (TRACE-P) mission: Synthesis of inventories, atmospheric modeling, and observations. Journal of Geophysical Research: Atmosphere, 111(D14). https://doi.org/10.1029/2006jd007118

Sun, Q., Meyer, W. S., Koerber, G. R., \& Marschner, P. (2020). Rapid recovery of net ecosystem production in a semi-arid woodland after a wildfire. Agricultural and Forest Meteorology, 291, 108099. https://doi.org/10.1016/j.agrformet.2020.108099

Sun, Y., Fu, R., Dickinson, R., Joiner, J., Frankenberg, C., Gu, L., et al. (2015). Drought onset mechanisms revealed by satellite solar-induced chlorophyll fluorescence: Insights from two contrasting extreme events. Journal of Geophysical Research: Biogeosciences, 120(11), 24272440. https://doi.org/10.1002/2015jg003150

Turner, A. J., Köhler, P., Magney, T. S., Frankenberg, C., Fung, I., \& Cohen, R. C. (2020). A double peak in the seasonality of California's photosynthesis as observed from space. Biogeosciences, 17(2), 405-422. https://doi.org/10.5194/bg-17-405-2020

Ukkola, A. M., De Kauwe, M. G., Roderick, M. L., Abramowitz, G., \& Pitman, A. J. (2020). Robust future changes in meteorological drought in CMIP6 projections despite uncertainty in precipitation. Geophysical Research Letters, 47(11), e2020GL087820. https://doi. org/10.1029/2020g1087820

van der Velde, I. R., van der Werf, G. R., Houweling, S., Maasakkers, J. D., Borsdorff, T., Landgraf, J., et al. (2021). Vast CO ${ }_{2}$ release from Australian fires in 2019-2020 constrained by satellite. Nature, 597(7876), 366-369. https://doi.org/10.1038/s41586-021-03712-y

van der Werf, G. R., Randerson, J. T., Giglio, L., van Leeuwen, T. T., Chen, Y., Rogers, B. M., et al. (2017). Global fire emissions estimates during 1997-2016. Earth System Science Data, 9(2), 697-720. https://doi.org/10.5194/essd-9-697-2017

Veefkind, J., Aben, I., McMullan, K., Förster, H., De Vries, J., Otter, G., et al. (2012). TROPOMI on the ESA Sentinel-5 Precursor: A GMES mission for global observations of the atmospheric composition for climate, air quality and ozone layer applications. Remote Sensing of Environment, 120, 70-83. https://doi.org/10.1016/j.rse.2011.09.027 
Vestreng, V., \& Klein, H. (2002). Emission data reported to UNECE/EMEP: Quality assurance and trend analysis \& presentation of WebDab. Norwegian Meteorological Institute.

Volkova, L., Aparicio, A. G. W., \& Weston, C. J. (2019). Fire intensity effects on post-fire fuel recovery in eucalyptus open forests of South-Eastern Australia. The Science of the Total Environment, 670, 328-336. https://doi.org/10.1016/j.scitotenv.2019.03.226

Wang, C., Corbett, J. J., \& Firestone, J. (2008). Improving spatial representation of global ship emissions inventories. Environmental Science and Technology, 42(1), 193-199. https://doi.org/10.1021/es0700799

Wang, J., Liu, Z., Zeng, N., Jiang, F., Wang, H., \& Ju, W. (2020). Spaceborne detection of $\mathrm{X}_{\mathrm{CO} 2}$ enhancement induced by Australian mega-bushfires. Environmental Research Letters, 15(12), 124069. https://doi.org/10.1088/1748-9326/abc846

Wang, J., Wang, M., Kim, J.-S., Joiner, J., Zeng, N., Jiang, F., et al. (2021). Modulation of land photosynthesis by the Indian Ocean dipole: Satellite-based observations and CMIP6 future projections. Earth's Future, 9(4), e2020EF001942. https://doi.org/10.1029/2020ef001942

Ward, M., Tulloch, A. I., Radford, J. Q., Williams, B. A., Reside, A. E., Macdonald, S. L., et al. (2020). Impact of 2019-2020 mega-fires on Australian fauna habitat. Nature Ecology \& Evolution, 4(10), 1321-1326. https://doi.org/10.1038/s41559-020-1251-1

Wunch, D., Toon, G. C., Blavier, J.-F. L., Washenfelder, R. A., Notholt, J., Connor, B. J., et al. (2011). The Total Carbon Column Observing Network. Philosophical Transactions of the Royal Society A, 369, 2087-2112. https://doi.org/10.1098/rsta.2010.0240

Yin, Y., Bloom, A. A., Worden, J., Saatchi, S., Yang, Y., Williams, M., et al. (2020). Fire decline in dry tropical ecosystems enhances decadal land carbon sink. Nature Communications, 11(1), 1900. https://doi.org/10.1038/s41467-020-15852-2

Yin, Y., Byrne, B., Liu, J., Wennberg, P. O., Davis, K. J., Magney, T., et al. (2020). Cropland carbon uptake delayed and reduced by 2019 midwest floods. AGU Advances, 1(1), e2019AV000140. https://doi.org/10.1029/2019av000140

Yin, Y., Chevallier, F., Ciais, P., Broquet, G., Fortems-Cheiney, A., Pison, I., \& Saunois, M. (2015). Decadal trends in global CO emissions as seen by MOPITT. Atmospheric Chemistry and Physics, 15(23), 13433-13451. https://doi.org/10.5194/acp-15-13433-2015

Yin, Y., Ciais, P., Chevallier, F., van der Werf, G. R., Fanin, T., Broquet, G., et al. (2016). Variability of fire carbon emissions in Equatorial Asia and its non-linear sensitivity to El Niño. Geophysical Research Letters. https://doi.org/10.1002/2016GL070971

Yoshida, Y., Joiner, J., Tucker, C., Berry, J., Lee, J.-E., Walker, G., et al. (2015). The 2010 Russian drought impact on satellite measurements of solar-induced chlorophyll fluorescence: Insights from modeling and comparisons with parameters derived from satellite reflectances. Remote Sensing of Environment, 166, 163-177. https://doi.org/10.1016/j.rse.2015.06.008

Zhang, Y., Xiao, X., Zhou, S., Ciais, P., McCarthy, H., \& Luo, Y. (2016). Canopy and physiological controls of GPP during drought and heat wave. Geophysical Research Letters, 43(7), 3325-3333. https://doi.org/10.1002/2016g1068501

Zheng, B., Chevallier, F., Yin, Y., Ciais, P., Fortems-Cheiney, A., Deeter, M. N., et al. (2019). Global atmospheric carbon monoxide budget 2000-2017 inferred from multi-species atmospheric inversions. Earth System Science Data, 11(3), 1411-1436. https://doi.org/10.5194/ essd-11-1411-2019 